\title{
Review
}

\section{Understanding Epigenetics in the Neurodegeneration of Alzheimer's Disease: SAMP8 Mouse Model}

\author{
Christian Griñán-Ferréa ${ }^{\text {, Rubén Corpas }}{ }^{\mathrm{b}}$, Dolors Puigoriol-Illamola ${ }^{\mathrm{a}}$, Verónica Palomera-Ávalos ${ }^{\mathrm{a}}$, \\ Coral Sanfeliu ${ }^{\mathrm{b}}$ and Mercè Pallàs ${ }^{\mathrm{a}, *}$ \\ ${ }^{a}$ Department of Pharmacology, Toxicology and Therapeutic Chemistry (Pharmacology Section) and Institute of \\ Neuroscience, University of Barcelona and CIBERNED, Barcelona, Spain \\ ${ }^{\mathrm{b}}$ Institut d'Investigacions Biomèdiques de Barcelona (IIBB), CSIC, IDIBAPS and CIBERESP, Barcelona, Spain
}

Accepted 11 January 2018

\begin{abstract}
Epigenetics is emerging as the missing link among genetic inheritance, environmental influences, and body and brain health status. In the brain, specific changes in nucleic acids or their associated proteins in neurons and glial cells might imprint differential patterns of gene activation that will favor either cognitive enhancement or cognitive loss for more than one generation. Furthermore, derangement of age-related epigenetic signaling is appearing as a significant risk factor for illnesses of aging, including neurodegeneration and Alzheimer's disease (AD). In addition, better knowledge of epigenetic mechanisms might provide hints and clues in the triggering and progression of AD. Intense research in experimental models suggests that molecular interventions for modulating epigenetic mechanisms might have therapeutic applications to promote cognitive maintenance through an advanced age. The SAMP8 mouse is a senescence model with AD traits in which the study of epigenetic alterations may unveil epigenetic therapies against the AD.
\end{abstract}

Keywords: Aging, DNA methylation, epigenetics, histone modification, neurodegeneration

\section{INTRODUCTION}

Today we are immersed in one of the most important processes that have occurred throughout the history of humanity: our world is getting old. Due to the increase in life expectancy, we have a large number of people over 60 years of age, up from 900 million in 2017, to nearly 2 billion in 2050 [1]. This fact would be a success in itself, but at the same time, diseases associated with aging have increased. In fact,

\footnotetext{
${ }^{*}$ Correspondence to: Mercè Pallàs, $\mathrm{PhD}$, Department of Pharmacology, Toxicology and Therapeutic Chemistry (Pharmacology Section) and Institute of Neuroscience, University of Barcelona, Avda. Joan XXIII s/n, 08028 Barcelona, España. E-mail: pallas@ub.edu.
}

aging has been established as the main risk factor for all types of dementia, such as Alzheimer's disease (AD). Thus, it is a challenge to understand the mechanisms that intervene in aging and neurodegeneration in order to prevent and/or treat chronic neurological diseases associated with the age.

The role of epigenetics in the control of transcriptional mechanisms comprises one of the earliest emerging fields in senescent processes. These aging-associated transcriptional signatures appear to be controlled by reciprocal regulation among chromatin-modifying enzymes, epigenetic marks, and microRNAs (miRNAs) [2].

In the last 17 years, epigenetics has been revealed as a crucial mechanism in the functioning of the 
nervous system and it participates in neuropsychiatric diseases as well as in cognition, learning, and memory formation [3]. Many neurological diseases are related to alterations in the epigenetic machinery, and more and more indications suggest their importance in many others. AD is no exception, and early studies are beginning to identify epigenetic alterations in this neurodegenerative pathology [4].

Senescence Accelerated Prone Mouse 8 (SAMP8) is a feasible model to study aging processes and, specifically, cognitive impairment and the molecular hallmarks of AD. Increasing evidence is found in the SAMP8 brain that links epigenetic changes with accelerated aging processes in this mouse strain. Consequently, we will present how epigenetic mechanisms interact and cooperate in the regulation of several targets that take part in senescence, cognitive decline, and AD-like pathobiology in SAMP8.

\section{BRAIN AGING AND ALZHEIMER'S DISEASE}

\section{Neurodegeneration in aging}

Aging induces a slow decrease in cerebral function, which leads to cognitive impairment, memory loss, motor disorders, and finally, can reach functional decay and death. Among the main features of aging, we might find genomic instability, telomere shortening, epigenetic alterations, loss of proteostasis, nutrient detection deregulation, mitochondrial dysfunction, cellular senescence, stem-cell depletion, and altered intercellular communication $[5,6]$. The brain is a high energy-consumption organ that requires about $20 \%$ of the body's total basal oxygen to function [7]. Therefore, alterations in the cerebral energy metabolism lead to disease, from subtle modifications in neuronal function to cellular death and neurodegeneration [8]. As aging progresses, the brain is susceptible to its intrinsic and extrinsic cell signaling and to the systemic environment. Studies performed on the brains of elderly subjects not previously diagnosed with a neurological disease have shown the presence of extracellular amyloid$\beta(\mathrm{A} \beta)$ and neurofibrillary tangles (NFTs), among other pathological alterations. These features might vary from individual to individual; the cause is not known or whether they could be the precursors of neurodegeneration. Some of them are probably the result of general aging processes. Alternatively, others might indicate a preclinical stage before AD clinical symptoms appear, which might last for decades [9]. In any case, the causes have not been identified that trigger the switch from normal aging to neurodegeneration and AD. Aging is a process regulated by different molecular and genetic mechanisms. There are four molecular longevity pathways known: decrease of insulin signaling; the increase of AMPK (AMP-activated Protein Kinase); the diminishing of TOR (Target of Rapamycin); and sirtuins.

In general, each cell possesses defense mechanisms to cope with oxidative stress (OS). These antioxidant defenses are endogenous enzymes and include superoxide dismutase (SOD), glutathione peroxidase, catalase, glutathione, thioredoxin reductase, and peroxiredoxins. Along with the aging process, several factors, such as a naturally decreased capacity of the antioxidant enzyme system, create an imbalance between antioxidant mechanisms and reactive oxygen system (ROS)-production equilibrium, accumulating ROS beyond the detoxifying capacity of the antioxidant system resulting in OS, eventually causing cellular damage that can no longer be repaired by internal mechanisms, finally leading to dysfunction of the system [10].

As previously mentioned, aging and neurodegeneration are closely related. The increase in OS, mitochondrial dysfunction, and the inflammatory response have been linked to accelerated aging and the progression of neurodegenerative diseases $[10,11]$. ROS and reactive nitrogen species are the main molecules contributing to OS. The most studied free radicals are superoxide $\left(\mathrm{O}_{2}{ }^{-}\right)$, hydrogen peroxide $\left(\mathrm{H}_{2} \mathrm{O}_{2}\right)$, hydroxyl $(\mathrm{HO})$, nitric peroxide $\left(\mathrm{ONO}_{2}{ }^{-}\right)$, and the nitric oxide free radical (NO). OS is the resulting redox state from disequilibrium between the generation and detoxification of ROS. Overproduction of ROS by the dysfunctional mitochondrion, in addition to the imbalance in mitochondrial fission/fusion and mitochondrial DNA mutations, can cause oxidative damage to the cells, inducing alterations to their biochemical and physiological functions and modify the genetic expression profiles inducing apoptosis and, thereafter, neurodegenerative pathologies [7, 12, 13].

Accumulative damage by free radicals over a certain time leads to major brain inflammation. Therefore, stress can also interfere with the homeostatic balance between anti- and proinflammatory cytokines and induce neurodegeneration. The cytokines are signaling proteins secreted by the cell in response to, predominantly, intra- and extraneuronal conditions. Neuroinflammation is a physiological response of the 
brain to an injury, infection, or disease in order to prevent a potential damage, neuronal destruction, or to dispose of a damaging agent. Several cytokines are small-secreted proteins released by both microglia and astrocytes in the central nervous system (CNS) during the inflammatory response. Stress can increase the levels of proinflammatory cytokines, such as tumor necrosis factor-alpha (TNF- $\alpha)$, interleukin 1 beta (IL)- $1 \beta$, and IL- 6 and can decrease the expression of anti-inflammatory cytokines IL-10, IL-4, and the transforming growth factor beta (TGF- $\beta$ ), exerting a harmful effect on neurogenesis, inducing cell death, and causing neurodegeneration [6]. Microglia activation is a key factor in $\mathrm{AD}$ progression and leads to increasing the chronic inflammatory state of the CNS during aging, caused by immune pathway dysregulation. Therefore, it is important to maintain control of microglial activation.

Another feature that has appeared as a central regulator of CNS aging is autophagy because it plays a crucial role as a control degradation point by which defective proteins, organelles, and other cellular constituents are sequestered in autophagosomes and delivered to lysosomes for degradation. Many of the detrimental modifications previously mentioned, such as proteostasis loss, nutrient detection alterations, mitochondrial damage, cellular senescence, and stem-cell depletion, could occur by means of basal autophagy deterioration and/or decrease of autophagic degradation activity during cellular stress, aging and neurodegenerative disorders $[14,15]$.

\section{Hallmarks of Alzheimer's disease}

$\mathrm{AD}$ is a progressive, devastating neurodegenerative disorder that leads to behavioral, cognitive, and memory deficits, as well as motor alterations [16]. AD patients suffer from language and learning difficulties, judgment loss, anxiety, depression, and irritability. AD etiology is still not clear, although there are some risk factors, both genetic and environmental. Neuropathological hallmarks of AD include lesions such as the presence of intracellular neurofibrillary tangles and the accumulation of $A \beta$ plaques in specific brain regions and cerebral amyloid angiopathy, reactive gliosis, and neuroinflammation [16], OS, calcium homeostasis disruption, neuronal and synaptic loss, altered functional connectivity among the brain areas, and, finally, neuronal loss and brain atrophy [17].

AD is classified into two types, familial and sporadic, depending on the etiology and the age of the patient when symptoms appeared. Familial AD (FAD) is inherited in an autosomal-dominant pattern with symptoms typically presented in the 4th or 5th decade of life. On the other hand, sporadic late-onset $\mathrm{AD}$ (LOAD) usually begins in the 7th-8th decade of life and is the more common of the two. The main risk factor for LOAD is aging $[18,19]$.

Increasing evidence suggests that $\mathrm{AD}$ pathogenesis is not restricted to the neuronal compartment, but includes strong interactions with immunological mechanisms in the brain [20]. However, it should be borne in mind that the elderly also have higher levels of inflammation. Therefore, in the literature, we often find the term inflammaging, although not as much as in $\mathrm{AD}$ patients.

Genome-wide association analysis suggests that several genes that increase the risk for sporadic AD encode factors that regulate glial clearance of misfolded proteins and the inflammatory reaction [20]. External factors, including systemic inflammation, changes in intestinal microbiota composition, and obesity, are likely to interfere with immunological processes of the brain and further promote disease progression [20-22]. Regarding FAD, the pathogenic mutations of the APP, PSEN1, and PSEN2 genes cause autosomal-dominant AD represented in less than $0.1 \%$ of the total AD cases [23]. The overwhelming majority of $\mathrm{AD}$ cases are sporadic and of unknown etiology. Currently, it is accepted that $\mathrm{AD}$ is a multifactorial disease; consequently, there is a remarkable effect of environmental factors in the etiology of $\mathrm{AD}$ [24]. Therefore, an adequate epigenetic intervention, beginning early in life as well as an elderly stage of life can identify and combat harmful molecular mechanisms through activation of neuroprotective gene expression such as the brain-derived neurotrophic factor $(B d n f), B c l 2$, and $B c l-X L$, among others, by environmental enrichment (EE) [25].

\section{EPIGENETICS}

Nowadays, more than twenty different epigenetic mechanisms have been identified [26-29], consisting mainly of processes that can directly modify the DNA, as in the case of DNA methylation, or modifications in the structure of chromatin, such as the modification of histones or alteration of the processes related to mRNA, such as, for example, non-coding RNA among which miRNAs were found.

The CNS is highly sensitive to environmental factors; thus, epigenetic disturbances are associated 
with neurological diseases [3, 30]. The CNS has a higher diversity of cell types with a highly specialized structural organization, tightly regulated by the epigenetic mechanism in response to the environment. In addition, expression patterns are being continuously modulated by brain activity, memory, and learning [31]. Alterations in the epigenetic information give rise to deregulation of the expression, resulting in the development of several pathologies, including AD.

\section{Methylation of DNA}

The only epigenetic mechanism that directly modifies mammalian DNA is methylation of the cytosine carbon ring in the dinucleotides of the $\mathrm{CpG}$ islands [32]. Most of the genome does not contain the dinucleotide $\mathrm{CpG}$ repeats; however, it concentrates on the so-called $\mathrm{CpG}$ islands, located in regulatory regions 5 ' of the genes. It is estimated that about $70 \%$ of $\mathrm{CpG}$ dinucleotides in the genome are methylated in normal somatic cells [33]. DNA methylation has been considered a normal mechanism of gene silencing with a crucial role in the transcriptional repression of repeated and centromeric regions. However, the mechanism is an efficiently regulated dynamic process in which methyl groups might be added or removed from both DNA strands. The result of both actions, methylation, and demethylation, is not permanent, which means that the mechanism of regulation is much more complex. However, some DNA methylation patterns are erased whereas others are maintained in the germline contributing to alter genes expression in a heritable manner without affecting the underlying genomic sequences. It should be kept in mind that most of the constitutive expression genes and a part of the tissue-specific genes and regulatory genes contain $\mathrm{CpG}$ islands in their promoter regions. While changes in DNA methylation occurs naturally during development, for example, inactivation of the $\mathrm{X}$ chromosome in females or the genomic imprint during development, where it is decided which parental allele will be expressed in the embryo [33], they also arise in response to external factors and aging, and are part of the modifications of various diseases such as fragile $\mathrm{X}$ syndrome, cancer, or neurodegenerative diseases, among many others.

DNA methylation is catalyzed by different members of the DNA MethylTransferase family (DNMTs) to form 5'-methyl-cytosine [34]. In mammalian cells, three different enzymes have been identified: DNA MethylTransferase 1 (DNMT1) and two de novo
MethylTransferase (DNMT3A and DNMT3B). During the $S$ phase, DNMT1 copies the methylation patterns of the parent strand to the daughter strand of DNA, so that methylation is inherited after cell division [35]. DNMT1 interacts with protein complexes involved in transcriptional repression, which include Histone DeACetylases family (HDACs) [36]. DNMT3A and DNMT3B are able to introduce a methyl group to unmethylated $\mathrm{CpG}$ dinucleotides to give methylated $\mathrm{CpG}$. In addition, there are two more methyltransferases, DNMT2 and DNMT3L; DNMT2 is different from all other DNMTs because it methylates cytosine 38 in the anticodon loop of aspartic acid transfer RNA, and DNMT3L differs from other DNMTs because it lacks catalytic motif and does not have methyltransferase activity but it contributes to de novo methylation process interacting with DNMT3A or DNMT3B [37-39]. Promoters that have been silenced by methylation can be reactivated, when demethylated. As for the mechanisms responsible for demethylation, there are two: passive demethylation, the mechanism of which arises by reduction or disappearance of DNMT1 function during replication, and active demethylation: this alternative mechanism is a catalytic removal of the methyl groups carried out by Ten-Eleven Translocation family (TETs) members of DNA hydroxylase family that oxidize the base and the subsequent action of the protein Thymine-DNA-Glycosylase, which will split the oxidized base.

\section{Hydroxymethylation of DNA}

5-hydroxymethylCytosine (5-hmC) was initially discovered in the $1950 \mathrm{~s}$ in bacteriophage and was observed in mammals in the 1970 s. It is the first oxidative product in the active demethylation of 5$\mathrm{mC}$. 5-hmC has been referred to as the "sixth base" because of its involvement in gene transcription in a similar way to 5-mC [40]. It has been detected that approximately $1 \%$ of cytosines in mammals are hydroxymethylated, although the level of hydroxymethylation varies depending on the tissue, with nervous tissue exhibiting higher levels [41]. Stem cells also have higher levels of 5-hmC decreasing during differentiation [41, 42]. 5-hmC is an intermediary of 5-mC demethylation. This mechanism has been demonstrated by the discoveries of different intermediates 5-formylCytosine (5-fC) and 5-carboxyCytosine (5-caC) in mouse genomic DNA [43]. The hydroxymethylation of the DNA is 
catalyzed by three enzymes belonging to the TETs. These comprise TET1, TET2, and TET3. This family of enzymes carries out repeated oxidations of 5-hmC into 5-fC generating 5-caC. In addition, TET1 and TET2 have demonstrated to play an important role in gene control and cell death in neurons [44], whereas TET3 is related to early embryonic-development processes [45]. Overall, hydroxymethylation of cytosine in a promoter gene or in CpG islands have been associated with an increase in gene transcription, i.e., it has an opposite effect to that of methylation [46].

In addition, these could affect the activity of different Methyl-CpG-binding domain proteins, thus modifying their recruitment during chromatin regulation or have direct effects on transcription. On the other hand, differential gene expression of TET enzymes was described at distinct stages of development or tissue. Regarding TET1, we found that it is expressed mainly in embryonic stem cells, whereas TET2 and TET3 are more common in all other tissue types [42].

\section{Chromatin remodeling and histone modifications}

Chromatin remodeling is a process that controls the dynamic chromatin structure to allow access of the genetic information encoded into the DNA. Such remodeling is principally carried out by posttranslational modifications (PTMs), which it requires the interactions between DNA methylation and histone modifications to change the accessibility of the transcriptional machinery. At least 16 histone modifications are known. As a result of a large number of modifications that can be done, there is a great potential for functional control of chromatin structure by histone modifications. However, an extra level exists due to the combination of different modifications give rise to the so-called "code of histones". This cross-talk can occur via multiple mechanisms [47].

As a consequence, these modifications mediate a variety of biological functions, including recruitment of protein machinery that modulate transcription, repair, and DNA replication. The "writers" are enzymes, which add specific PTMs to histone substrates making the chromatin in compacted or relaxed conformation, and leads to transcriptional repression or activation, respectively, and are divided into classes based on the specific PTM they affect. In contrast, "erasers" are enzymes that remove specific PTMs from histone substrates restoring the interaction between the histone and DNA, and are divided into PTM-specific classes. Finally, "readers" do not alter the histone and recognize either post-translational marks or combination of marks and histone variants. These proteins will act as effectors, being responsible for the activation or repression of transcription and chromatin packaging, among others.

Therefore, a wide variety of modifications exist as a consequence of the enzymatic activity of antagonistic complexes, mainly including acetylation, methylation, phosphorylation, ubiquitination, sumoylation, ADP-ribosylation, and adenylations. These tags participate in the regulation either by altering the interactions of DNA and histones or by generating a recognition platform necessary to recruit to the proteins readers with different activities.

\section{Histone acetylation and deacetylation}

Proteins with lysine acetyltransferase activity have been identified and characterized with an important role in gene regulation $[48,49]$. These enzymes acetylated histone tails on the $\varepsilon$-amino of lysine residues. Both proteins, the histone acetyl transferases (HATs) and HDACs, do not bind directly to DNA but act on it through a multicomplex that includes transcription co-activators and co-primers $[50,51]$. This process leads to the activation of transcription by neutralizing the positive charge of the lysine, causing a reduction in the affinity of histones for DNA. The degree of histone acetylation at specific genomic sites is the net result of a balance between these enzymes.

The acetylation process is carried out by several HATs (Table 1). In general, these form part of the multi-component complexes, grouping in different families:

HDACs catalyze the removal of the acetyl group from $\alpha$-acetyl-lysine [52], decreasing the acetylation levels. Hypoacetylation increases chromatin compaction leading to transcriptional repression [53]. Modulation of the activity of HDACs occurs through protein-protein, post-translational modifications (sumoylation, phosphorylation, and proteolysis), subcellular location/translocation, and the availability of metabolic co-factors [54].

At least 18 HDACs genes have been identified in the human genome [55]. All HDACs perform multiple cellular functions of great importance, and the deregulation of HATs and HDACs are implicated in the progression of several pathologies, including $\mathrm{AD}$ and the senescence process. Among HDACs, sirtuins are NAD+ dependent deacetylases that exhibit 
Table 1

HAT families and acetylated sites

\begin{tabular}{lll}
\hline HAT families & & Sites of Histone Modifications \\
\hline GNAT/PCAF & Gcn5, PCAF, ELP3 & H3K9, H3K14, H3K18, H4K5, H4K8, H4K12, H4K16 \\
MYST & Tip60, MOZ, MORF, HBO1, HMOF & H3K14, H4K5, H4K8, H4K12, H4K16 \\
p300/CBP & p300, CBP & H2AK5, H2BK12, H2BK15, H3K14, H3K18, H4K5 \\
\hline
\end{tabular}

Table 2

Histone methylation enzymes

\begin{tabular}{lll}
\hline Methylase enzymes & Description & Activity \\
\hline Histone Methyl & Histone-specific lysine & Methylations in histones H3 (residues \\
Transferases (HMTs) & methyltransferases containing the SET & K4, K9, K27, and K36) and H4 (K20). \\
& domain (Su (var) 3-9, Enhancer of & \\
& Zeste, Trithorax) & \\
& Lysine methyl-transferases without SET & Methylate to H3K79 \\
& domain & Methylate- distinct arginine residues in \\
& Arginine methyltransferases & histones H3 and H4 \\
Histones DeMethylases & LSD demethylases function as & \\
(HDMs) & FAD-dependent amino acids (flavin & \\
& adenine dinucleotide) & \\
& JMJC demethylases function as & \\
& 2-oxo-glutarate-FE (II)-dependent & \\
& dioxygenase & \\
\hline
\end{tabular}

neuroprotective effects against cerebral age-related disorders [56]. In mammals, there are seven sirtuins homologs called SIRT1-7, with different locations and enzymatic activities [57]. The most preserved family member is SIRT1, a nuclear protein that has been widely investigated in neurodegenerative diseases [58].

\section{Histone methylation}

Histone methylation is an epigenetic marker that is more stable than the acetylation of histones. This takes place in the lysine and arginine side chains of histones [59]. The enzymes responsible for the methylation of specific residues are denominated HMTs and can be grouped into three different families, as depicted in Table 2. These three families, in turn, contain several subfamilies classified by the methylation that they produce. Methylation of arginine residues is common in eukaryote organisms. Note that while arginine methylation is mainly related to transcriptional activation, the same lysine modification might be associated with the activation and repression of gene expression, depending on the modified site and the degree of methylation of each residue.

Histone methylation is reversible and highly dynamic, and homeostasis of methylation is maintained by the antagonistic activity of the writers and erasers of methylation, which are responsible for establishing and eliminating methylation markers, respectively [60]. This process of histone demethylation is carried out by the Histone DeMethylases family (HDMs) (Table 2).

\section{Other histone modifications}

Other modifications of histones, such as phosphorylation, ubiquitination, sumoylation, ADPribosylation, deiminiation, and proline isomerization, intervene to a lesser extent in post-translational modifications of histones, thereby regulating transcription $[61,62]$.

\section{Non-coding RNAs and microRNAs}

Analysis of the transcriptome has revealed that, although it depends on the species, only $1.5 \%$ of the genome encodes RNA that culminate in protein transcripts, resulting in a broad repertoire of transcripts, more than $65 \%$, of RNA that are not translated into proteins and that are called non-coding RNA (ncRNA). Non-coding RNA are classified depending on their size, as (lncRNA, "Long non-coding RNA") with more than $200 \mathrm{nts}$, and as ("Short non-coding RNA", sncRNA), of less than 200 nts. There are several subtypes between sncARN and lncRNA, many of which are involved in the regulation of gene expression and can be grouped according to the genomic origin and biogenic processes [63, 64]. 
MicroRNAs are small non-coding RNA molecules between 18 and 25 nucleotides that are expressed in the eukaryotic nucleus in both intra- and intergenic regions and that are responsible for the repression of gene expression $[65,66]$. miRNAs vary in their mechanism of action depending on the degree of complementarity with their target mRNA, as follows: 1) inhibition of translation; 2) stopping the elongation phase; 3 ) the premature arrest of ribosomes; and 4) degradation of mRNA at the cotransduction level.

There are 28,645 identified miRNAs precursors expressing approximately 35,828 mature miRNAs in 223 species [66, 67]. It is estimated that between 30 and $90 \%$ of human genes might be regulated by miRNAs, and each miRNA can regulate up to 100 genes, which could potentially regulate a large number of protein-coding genes [68].

The first described miRNA was lin-4 in Caenorhabditis elegans [69]. The relevance of this study was its demonstration of the implication of miRNAs in the development of C. elegans. Subsequently, several studies were carried out involving miRNAs in programmed cell death in flies [70], in early and late vertebrate development [71, 72], as well as in certain physiological functions in humans, such as adipocyte differentiation, antiviral defense, neuronal development, or apoptosis [73], with a very profound impact in cardiovascular diseases [65, 74], diabetes [75], schizophrenia [76], and neurodegenerative diseases such as $\mathrm{AD}$ [73].

\section{Interactions among epigenetic mechanisms}

All of the machinery of histone-modifying enzymes does not act independently, as has been mentioned, but is associated with large multiprotein complexes that, together, modify chromatin structure regulating gene transcription. In turn, miRNAs regulate gene expression in which a profound interaction between different epigenetic modifications is established. Thus, a strong relationship is observed between the methylation of DNA and the modifications of the histones that, acting together, are able to regulate the majority of the transcription process along the whole genome. In addition, histone modifications have been found to play a positive or negative role in controlling the expression of miRNA genes from both normal and pathological cells [77, 78]. On the other hand, miRNAs exert beneficial effects on the regulation of DNA methylation or histone modification through the direct regulation of both histone-modifying enzymes and chromatinremodeling complexes [79].

\section{EPIGENETIC MODULATION DURING AGING AND AD}

Changes in the epigenome during aging lead to alterations in gene regulation and genomic instability, mainly contributing to the appearance of age-related diseases such as cancer and neurodegenerative diseases, among others [2]. As mentioned earlier, aberrant gene expression, genomic instability, and the loss in chromatin structure are three of the characteristics associated with both aging and multifactorial or complex diseases $[5,80]$. These alterations are intrinsically linked to changes in the epigenome $[81,82]$ and may be altered by environmental factors [24]. There is evidence that shows 5-mC change over time. Consequently, changes in methylation patterns might be linked to the aging process; these changes are also associated with a decrease in organ function, memory loss, bone density, and other health problems [83]. Normally, a global decline in DNA methylation is the predominant event in aging. For instance, in the senescent cells of mice and humans, global hypomethylation is produced, in comparison with the young cells [2].

However, age-related reduction in global 5-mC levels does not affect repetitive DNA equally indicating that individual sites, especially $\mathrm{CpG}$ islands, become hypermethylated during aging. Furthermore, in humans and mice, the $\mathrm{CpG}$ islands are in close proximity to the promoters, which are typically hypermethylated with age. It is interesting to note that genes affected or modulated by these changes are those encoding proteins related to differentiation, development, inflammation, apoptosis, or senescence, among others, are related to the neurodegenerative process.

Regarding the chromatin remodeling, and specifically the acetylation process, an increase in the global acetylation patterns of histones $\mathrm{H} 3$ and $\mathrm{H} 4$ during aging has been reported [84]. Likewise, the deregulation of cellular autophagy, one of the characteristic signs of aging, is associated with an increase in the acetylation of histone $\mathrm{H} 3$ and changes in methyltransferase G9a activation [85].

Alterations in global methylation of histones $\mathrm{H} 3$ and $\mathrm{H} 4$ levels have been described during aging and neurodegeneration [86-88]. These changes are also produced in response to negative environmental mod- 
ifications that produce stress and anxiety [89] and cellular damage [88]. In addition, TET1 and TET2 are associated with aging and neurodegeneration [80]. In this regard, it is noteworthy that modifications in gene expression of epigenetic enzymes, such as the underexpression of DNMT 1 and 3A, as well as of HMTs, GLP, and G9a, in differentiated neurons cause alterations in memory and learning [90-92]. Of note, reduced expression of HDACs in both HDAC2 and HDAC3 facilitates learning and memory formation, in turn increasing the number of dendrites and synapses [93, 94]. Finally, the association between neuronal activity generated in each psychological condition ranging from healthy, stress disorder, addiction, and depression to neurodegenerative disorders such as $\mathrm{AD}$ is capable of modifying the levels of 5-mC and 5-hmC, as well as histone marks, and memory and learning are supported by epigenetic modifications [95-99].

Furthermore, a specific demethylation of $\mathrm{H} 4 \mathrm{~K}$ 20me and H3K36me3, among others, and an increase in positions H3K27me3, H3K79me, and H4K20me3 occur with age $[89,100,101]$. Additional evidence is the alteration in protein levels of EZH2, a methyltransferase responsible for methylation at the H3K27 site, which is decreased in senescent cells [102].

Moreover, changes in the expression of class I HDACs enzymes, such as HDAC1 and HDAC2, leading to impairment in spatial and in contextual memory, have been described [103-105]. In addition, the involvement of class III HDACs, such as SIRT1, SIRT2, and SIRT6, has been described in memory formation and neurodegenerative processes [10, 106, 107]. Different studies have shown that SIRT1 has a protective effect against AD [108] since it can prevent the formation of $A \beta$ peptides deacetylating RARb (Retinoic Acid Receptor beta) and activating alpha-secretase ADAM10 [109]. SIRT1 deacetylates tau and leads to its degradation, and in turn preventing its accumulation [110]. Otherwise, the epigenetic marker H4K16ac, a substrate of deacetylase enzyme SIRT2, increases during aging. Similarly, it has been observed that SIRT6 deficiency affects longevity and causes premature aging [111]. Finally, the inhibition of other HDACs, such as class I HDACs [103], improves cognitive impairment in aged mice by increasing the acetylation of H4K12 [112, 113] opening new avenues of AD therapies [114]. The literature reveals that at least $70 \%$ of known miRNAs are expressed in the brain [115]. A correlation has been demonstrated between changes in the expression of genes coding for miRNAs during aging and disease and is also associated with changes in life expectancy [116]. Furthermore, the underexpression of various miRNAs inhibits senescence, and the overexpression of some miRNAs promote it, appearing to be one of the causes of senescence [117] as well as increased global expression of miRNAs during aging [118]. Interestingly, the location of the miRNAs within the cells, and specifically in the neuron, is a specific feature of each miRNA. Different miRNAs can be found in the synaptic region (e.g., $m i R$-7), in the neuronal axon (e.g., miR-16), or in the dendrites (e.g., $m i R-26)$. It is well known that the cortex and hippocampus are two brain regions that are especially rich in miRNAs expression, also being the main cerebral areas involved in learning and memory processes and neuronal plasticity [119].

Different microarrays studies indicate a general increase in pro-oxidant and inflammatory genes in the brain of aged rodents in comparison with adults and implication for miRNAs has been described [120]. Moreover, cellular response to OS, an inducer of genomic instability, induces the expression of miRNAs that in turn, reduce protein levels involved in DNA repair and in genes related to oxidative phosphorylation leading to an increase in ROS. Therefore, mitochondrial dysfunction suffers a loss of antioxidant capacity [121], the same one involved in the aging process [122].

Some of the miRNAs implicated in the regulation of inflammation are $m i R-124$ and $m i R-29$. $m i R-124$ is expressed at higher levels in the brain more than in the periphery, and some studies suggest a reduction on this miRNA in the aged brain, although this decline has only been observed in a small subpopulation of microglia [123, 124]. miR-29 has been found at higher levels within CNS microglia. One of the most important changes in the brain of AD patients is upregulation of the expression of the beta-secretase BACE1 [125]. It has been shown that $m i R-29$ strongly inhibits BACE1 in vitro and is markedly downregulated in sporadic AD patients. Surprisingly, the opposite has been found for non-pathological aging [120].

As mentioned previously, aging is the main risk factor for developing neurodegeneration, and it has become clear that in $\mathrm{AD}$, many mechanisms are involved that are also implicated in aging, interacting in a complex way. The potential reversibility of epigenetic changes that occur as a result of aging offers interesting opportunities to alter the path of age-related diseases. The following table listed some epigenetic modifications occurring in aging and $\mathrm{AD}$ (Table 3). 
Table 3

Epigenetic modifications during aging and $\mathrm{AD}$

\begin{tabular}{|c|c|c|}
\hline Observation & Tissue or sample & Reference \\
\hline Hypomethylation of the APP protein promoter & Human brain & [126] \\
\hline Hypomethylation of the promoter of ribosomal genes with aging & Human stem cells & [91] \\
\hline Reduction in DNA methylation & Human prefrontal cortex & [127] \\
\hline Difference in DNA methylation in discordant twins for $\mathrm{AD}$ & Human temporal cortex & [128] \\
\hline Influence of steroids and aging on the methylation of the APP promoter & Mouse brain & [129] \\
\hline Response to the metabolic stimulus of the PSEN1 gene regulated by DNA methylation & Mouse brain & [130] \\
\hline Hypomethylation of proinflammatory genes: iNOS, IL-1, and TNF & Human cortex & [131] \\
\hline Increased phosphorylation of histone $\mathrm{H} 3$ & Hippocampal neurons & [132] \\
\hline Increased acetylation of histone $\mathrm{H} 3$ and $\mathrm{H} 4$ & Mouse neurons & {$[133]$} \\
\hline Modification of the expression of chromatin regulatory enzymes & Mouse brain & [84] \\
\hline Dysregulation of several miRNAs, overall increase in patients with $\mathrm{AD}$ & Mouse brain & {$[134]$} \\
\hline
\end{tabular}

\section{SAMP8 MOUSE MODEL}

The AD experimental models most widely used at present are transgenic mice based on familial $\mathrm{AD}$ mutations causing early-onset and severe AD pathology $[135,136]$. Therefore, $\mathrm{AD}$ transgenic mice develop amyloid and/or tau pathology earlier than cerebral age-related changes, while the age is the main risk factor in the sporadic AD. To emulate known AD risk factors, such as abnormal cholesterol and insulin metabolism, some developed mice models overexpress transgenes of APOE $\varepsilon 4$ and leptin, among others [137]. At present, there is a reappraisal of the validity of naturally occurring models by using aged animal species, such as fruit flies, rabbits, dogs, and the guinea pig relative, Octodon degu, which reproduce physiological changes appearing in sporadic AD [138]. An also widely used rodent model, faithful of these sporadic cases is the Senescence-Accelerated Prone Mouse 8 (SAMP8). This mouse-inbred strain provides interesting and advantageous non-transgenic mice models for research in AD [139, 140].

SAMP8 was established through phenotypic selection from a common genetic pool of $\mathrm{AKR} / \mathrm{J}$ mice strain and exhibits age-related deterioration in learning and memory abilities compared with the control strain, Senescence-Accelerated Resistant Mouse 1 (SAMR1), established from the same AKR/J strain [139]. Among a variety of age-related pathologic phenotypes shown by SAMP inbred strains, SAMP8 develops early AD-like pathology [140].

SAMP8 mice have been proposed as a model for studying the triggering and development of mild cognitive impairment, early neurodegenerative AD-like changes, and the progression of $\mathrm{AD}$ pathogenesis [141]. It is assumed that the abnormality in senescence and memory function observed in SAMP8 mice depends on several factors, including morphological, neurochemical, and neuropathological changes [142]. Moreover, it is feasible that differences among SAM strains could be explained on the basis of epigenetics, specifically in alterations that give rise to changes in chromatin status [143].

\section{SAMP8: Evidence as a sporadic Alzheimer's disease model}

SAMP8 mice exhibit an accelerated aging phenotype with external signs of hair loss and lack of hair glossiness, periophthalmic lesions, increased lordokyphosis, and reduced physical activity [144, 145]. The sensorimotor performance of SAMP8 mice also deteriorated with advancing age at a higher pace than in SAMR1 mice [146]. Other senescence traits include hearing impairment, deficits of immune response, and lifespan shorter than that of control SAMR1 mice [144]; namely, median life expectancy was around 10 months for SAMP8 and 17 months for SAMR1 [147, 148]. At the CNS level, SAMP8 demonstrate deficits in learning and memory and emotional disorders. It is interesting to point out that among the diverse SAMP strains of accelerated senescence, only SAMP8 and SAMP10 showed learning and memory defects [144]. Therefore, the cognitive impairment of these strains might be related to a few recessive genes among the many genes controlling aging of the brain [149]. Furthermore, underlying mechanisms are different for both strains, as SAMP8 mice show AD-related traits, whereas SAMP10 cognitive impairment is related to brain atrophy [150]. Similarly, in humans, old age is a risk factor for $\mathrm{AD}$, but it does not unavoidably lead to the disease in centenarians or, in the case of dementia, it might not progress to AD. Therefore, only SAMP8 mice seems to be accelerated senescence after nor- 
mal development, but no other senescent strains show progression into $\mathrm{AD}$-like dementia.

Learning and memory impairment of SAMP8 was first demonstrated in passive avoidance task, where mild deficits were already evident at 2 months of age and increased with advancing age [151]. These authors demonstrated only minor impairments in the Morris Water Maze (MWM) test at early age. A number of successive studies confirmed the defective cognitive capacities of SAMP8 mice in a variety of experimental tasks including MWM, radial arm mazes, T/Y-maze, and passive avoidance and active avoidance were clearly established at 8-12 months of age $[141,152,153]$. However, current experimental interests rely on the analysis of early pathogenic mechanisms of age-related neurodegeneration. In AD dementia, the pathological brain processes are known to develop for decades before cognitive impairment can be detected clinically. Therefore, there are clinical interests in moving to the phases of the preclinical $\mathrm{AD}$ and early mild cognitive impairment for new clinical trials against $\mathrm{AD}[154,155]$. Recent studies with SAMP8 mice established the presence of cognitive impairment in these mice compared to SAMR1 mice at the age of 4-6 months in instrumental conditioning (passive avoidance and active avoidance), spatial learning and memory (MWM, radial maze, and object location test), and recognition memory with novel object recognition test (NORT) [156-161].

Therefore, cognitive deficits in SAMP8 mice have been characterized in a range of validated tests and there is an agreement on the early and progressive cognitively impaired responses of these mice [161, 162]. There were reported inconsistencies only in the T-maze test [164, 165]. One of the best-characterized responses is that of spatial learning and memory in MWM. SAMP8 mice demonstrated a deteriorated and progressively impaired response in this hippocampus-dependent task [146]. Indeed, the hippocampus, a brain area that is highly sensitive to $\mathrm{AD}$, is severely affected by pathological alterations in these mice. Furthermore, age-related behavioral and cognitive alterations occurring in the SAMP8 are evident at 4 months in comparison with SAMR1 [165].

Regarding emotional disorders, SAMP8 exhibited reduced anxiety-like behavior in the Plus Maze Test (PMT), lower neophobia, and lower emotionality and higher hyperactivity in the Open Field Test (OFT) than SAMR1 mice [146, 160, 163, 166]. These alterations of non-cognitive behavior were significant in 4-month-old SAMP8 and increased with advancing age. Furthermore, other authors described an enhancement of depression-like behavior in the Forced Swim Test $[161,167]$ and a decrease of social interaction [168]. Thus, SAMP8 mice show alterations of non-cognitive behavior that do not generally model the behavioral and psychological symptoms of dementia (BPSD) associated with AD. BPSD behaviors are mainly driven by AD pathology in the cortical and basal ganglia areas, where pathology in the SAMP8 mice might be less severe than in the several strains of $\mathrm{AD}$ transgenic mice that reproduce these typical neuropathological changes of AD [169].

The analysis of functional alterations underlying the cognitive impairment of SAMP8 mice revealed deficiencies in the mechanism of long-term potentiation (LTP). LTP is based on long-term synaptic plasticity and memory formation [170]. LTP recordings in vivo [158] or in hippocampal slices [171-173] showed a correlation between deficits in synaptic circuitry responses and the cognitive impairment of these mice. The ratio of the electrophysiological recordings of the paired-pulse stimulations, which is on the basis of short-term synaptic plasticity, also demonstrated deficiencies in SAMP8 mice in vivo [158] and in hippocampal slices [173]. Reduction of synaptic markers, such as PSD95 and synaptophysin [174, 175], corroborated the hippocampus plasticity deficiencies of SAMP8 mice. Furthermore, reduced levels of glial cell line-derived neurotrophic factor (GDNF) in the hippocampus of SAMP8 mice were demonstrated transiently at an early age of 2-5 months compared to SAMR1 mice hippocampus [176]. GDNF has been reported as highly neuroprotective against cognitive loss in a mouse model of $\mathrm{AD}$ [177]. Another neurotrophic factor, the BDNF, was also reported reduced in the SAMP8 mice hippocampus $[174,178,179]$. Indeed, the reduction of BDNF was concomitant to the decrease of the activation of associated signaling factors Calcium-calModulindependent Kinase II (CaMKII) and CREB [171]. The reduced activation of the synaptic plasticity pathway CaMKII-CREB-BDNF in SAMP8 may be derived from a dysfunction of the NMDA receptor in these mice [171]. An age-related loss of cholesterol in the brain was proposed as the cause of the reduction of this pathway [180]. Indeed, a diet supplemented with plant sterols prevented the LTP reduction and cognitive impairment shown by SAMP8 mice [172]. Reduced levels of BDNF and of phosphorylated CaMKII in the hippocampus and in the cortex of AD patients are suggested to contribute to the atrophy and memory impairment in the disease [181, 182]. 
Additionally, there is a derangement of cholesterol metabolism in the AD brain [183].

SAMP8 mice showed higher levels of $A \beta$ peptides and neurotoxic $A \beta$ oligomers than SAMR1 mice, as demonstrated by ELISA and western blot techniques, respectively [174]. This increase would be caused by an abnormally elevated synthesis of the amyloid- $\beta$ protein precursor (A $\beta P P)[184,185]$. Strikingly, an increase in the transcription of $A \beta(A 4) P P$ gene was detected as early as 2 months of age [184]. Concurrently, increased transcription of Bacel and decreased transcription of Adam 10 would favor the amyloidogenic processing pathway of A $\beta P P$ [184]. A decrease of the $A \beta$ metabolizing enzyme Insulin-degrading enzyme (Ide) reported at 6 months of age might also contribute to amyloid pathology in SAMP8 mice [174]. Furthermore, age-related increase in presenilin 1 in SAMP8 mice, but not in control strain SAMR1, might also contribute to the imbalance in the $A \beta P P$ processing [186]. A diminution of $A \beta$ clearance derived from disturbances in the blood-brain barrier [187] is another significant factor leading to amyloid pathology in these mice. The relevance of $\mathrm{A} \beta$ neurotoxicity in the SAMP8 phenotype was corroborated by the protection against cognitive loss afforded by the peripheral administration of an antisense oligonucleotide against the $A \beta$ region of $A \beta P P$ [188] or an antibody against $A \beta_{42}$ [184]. It is known that the sequence of murine $A \beta$ peptide differs in three amino acid residues from human sequence, this diminishing the capacity to produce amyloid deposits except in the case of murine AßPP-bearing mutations of human familial AD [189]. However, several laboratories have documented the presence of $\mathrm{A} \beta \mathrm{PP}$ or $\mathrm{A} \beta$ immunoreactive granular structures in the SAMP8 brain, although devoid of the $\beta$-pleated sheet of human fibrillary $A \beta$ in AD plaques [190]. Clustered granules devoid of $A \beta$ and containing glycoside components were also identified early in the SAMP8 hippocampus; these attributed to senescence processes [191, 192]. Therefore, amyloid pathology is well established in SAMP8 mice, although the chemical characteristics of murine $A \beta$ do not allow for its deposition in amyloid plaques. In the human disease, $A \beta$, both by increased accumulation in target brain areas and by the decreased presence in CSF, is the earliest biomarker known for being detected in preclinical phases of AD [193]. Similarly, the accumulation of $A \beta$ in SAMP8 brain comprises an early event in its progression to an AD-like phenotype.

Pathological accumulations of hyperphosphorylated tau (p-tau) were detected in the hippocampus and cortex areas of SAMP8 mice. Analysis of ADrelated tau phosphorylation sites revealed increases of p-tau in SAMP8 mice compared to SAMR1 mice aged between 3 and 9 months [174, 178, 184, 194-196]. Tau pathology is induced by the increased activity of specific kinases, as supported by the reported increased levels of activation of the kinases Cdk5 [194-196], GSK3ß Tyr216 [178], and JNK1 [174]. It is not known whether tau pathology progresses after amyloid accumulation or whether both are parallel derangements in the SAMP8 mouse brain. However, peripheral administration of an antisense oligonucleotide directed at GSK3 $\beta$ Tyr216 improved learning and memory in SAMP8 [197]. In any case, the SAMP8 mice model spontaneously reproduces both pathologies, similarly to most sporadic AD cases. Contrariwise, AD transgenic mice might bear familial tauopathy genes in addition to the familial AD genes to exhibit significant tau pathology.

OS is a harmful imbalance of redox homeostasis common to both brain aging and AD [198]. Changes in OS including a decrease of antioxidant defense enzymes, an increase of markers of oxidative damage, and an increase of mitochondrial DNA deletions were reported in the brain tissue of SAMP8 mice as early as 2 months of age [199-201]. Signs of OS increased along early and advanced age in SAMP8 mice compared to SAMR1 mice [195, 202-204]. Oxidative alterations were also present in peripheral tissues at a range of age [200, 205-207]. OS might be induced or worsened by mitochondrial alterations. Indeed, brain mitochondrial respiration was dysfunctional at 2 months of age, demonstrating lower activity of complex III [201-207]. Mitochondrial dysfunction plus either increased generation of ROS or lower antioxidant defense was demonstrated in both neurons and astrocytes cultured from SAMP8 embryonic brain tissue [208-210]. SAMP8 liver mitochondria were also dysfunctional but at later age of 6-12 months [203, 211-213]. The activities of $A \beta$ are numerous and yet to be fully elucidated. However, it is well accepted that the imbalanced in production and degradation of $\mathrm{A} \beta$ produces the neurodegeneration of $\mathrm{AD}$ and provoking physiological effect in the brain $[214,215]$. Likewise, the increased burden of A $\beta$ in the SAMP8 brain might contribute to earlier mitochondrial dysfunction and this impairment might be worsened by the presence of p-tau in the SAMP8 brain [216]. Furthermore, in vivo and in vitro studies support that $\mathrm{A} \beta$ generates free radicals, inducing protein oxidation, lipid peroxidation, and DNA damage [217-221]. Accordingly, the treatment of 12-month-old SAMP8 
with antisense oligonucleotide directed against the $A \beta$ region of APP decreased the levels of both $A \beta$ and oxidative markers [222], improving cognition. Although the interaction among $\mathrm{A} \beta$, OS, and $\mathrm{AD}$ pathology is not well understood, a vicious cycle is proposed in which alterations induced by OS would increase accumulation of $A \beta$ and the subsequent $A D$ pathology, the latter in turn increasing mitochondrial dysfunction and OS [223]. Despite the weight of OS in $\mathrm{AD}$, antioxidant therapies were demonstrated ineffective in clinical trials [224]. Therefore, the SAMP8 model with spontaneous OS, mitochondrial dysfunction, and $A \beta$ and p-tau accumulation in the brain makes a useful model defining the mechanisms of free radicals and mitochondrial dysfunction in $\mathrm{AD}$ [162].

Neuroinflammation is another age-related process that, together with OS, paves the way for the development of neurodegenerative diseases. Inflammatory signaling might contribute to $\mathrm{AD}$ triggering and progression [225, 226]. Phenotypical traits of inflammaging with higher expression of inflammatory mediator molecules were found in the SAMP8 hippocampus at an early age of 2 months [24]. There was also an increased response to acute inflammatory injuries at 3 months of age in SAMP8 compared to SAMR1, as detected by the levels of circulating proinflammatory cytokines [227]. Inflammation was also detected in peripheral tissues such as liver [228]. Inflammatory markers were generally maintained at elevated levels with increasing age in the SAMP8 brain in comparison with SAMR1 [24, 229, 230]. Chronic inflammation in the SAMP8 hippocampus was aggravated by deficiencies in the mechanisms of resolution of inflammation [231]. Therefore, SAMP8 mice could not counteract inflammaging, and this might contribute to the development of its sporadic AD-like phenotype. At the cellular level, reactive astrocytosis was shown in the SAMP8 hippocampus $[24,179]$. In this respect, astrogliosis measured the GFAP marker that was present at 2 months of age in SAMP8 mice, and maintained in old age [232], thus confirming the onset of neuroinflammation at early age. A decrease of the inflammatory regulator Rcor2 might mediate the inflamed phenotype of SAMP8 astrocytes [227]. Age-related stressmediated activation of transcription factor NF- $\mathrm{k} \beta$ was another proposed molecular mechanism of pathological inflammation in SAMP8 [228, 233]. Although diverse transgenic mice models of $\mathrm{AD}$ reproduce $\mathrm{OS}$ markers, neuroinflammation and gliosis appear only at the advanced age and is associated with a heavy load of amyloid plaques [139, 140]. Neuron loss, one of the hallmarks of $\mathrm{AD}$, has been described in the hippocampus of 8-month-old SAMP8, paralleling an elevated stage of neurodegeneration [234]. Hippocampus, the most affected brain area in SAMP8, is an essential area for memory function and its functional circuitry is very sensitive to AD pathology. In addition to the AD-like neuropathology discussed earlier, SAMP8 showed a progressive impairment of cholinergic neurotransmission, as reported at 8 months of age in the hippocampus and cerebral cortex [165], similarly to the main neurotransmission defects observed in AD patients [235].

Proteomics, metabolomics, genomics, and transcriptomics studies of SAMP8 brain tissue confirmed the presence of AD-like pathological traits in the brain of SAMP8 mice [236-240]. As a whole, the specific senescent-associated alterations in SAMP8 brain comprise a scenario for the development and progression of an AD-like phenotype including the main AD traits of neuropathology and memory loss. Therefore, SAMP8 is an excellent mice model to analyze mechanisms and therapies for sporadic AD, whose main risk factor is advancing age.

\section{Epigenetics of aging and sporadic Alzheimer's disease-like phenotype in SAMP8}

As mentioned previously, the SAMP8 model has been widely used to study senescence in all systems and from different points of view, including cerebral senescence [139, 144]. SAMP strains were generated by the phenotypic selection of crosses between siblings but, as mentioned extensively in the introduction, the causes of accelerated senescence have not been established.

The participation of OS, the evolution of neuroinflammation, and its correlation with changes in behavior and cognitive impairment, including the alterations in gene expression and protein aberrations associated with aging and neurodegenerative processes, are SAMP8 strain characteristics well reported. The fact that the SAMP8 mouse is a spontaneous animal model and not transgenic mice model of AD suggests that the underlying orchestra mechanisms must be linked to epigenetics. In this respect, several results corroborate the existence of epigenetic modifications related to aging and neurodegeneration in SAMP8 [25, 227]. It is well known that epigenetic machinery is highly modulated by environmental factors such as diet or exercise. Moreover, several studies in SAMP8 demonstrated that exercise [25], EE [233], or resveratrol-enriched diet [148, 241] 
induced changes in the expression of Sirtl, one of the class III HDACs related to epigenetic marks. Therefore, all this evidence indicated that SAMP8 strain is affected by epigenetic changes in reference to SAMR1 that favors mice to accelerate senescence and present $\mathrm{AD}$-like processes.

For instance, EE increased global 5-mC levels in younger SAMP8 (2 months old), accompanied by reduced 5-hmC levels. Changes in gene expression of Dnmt3b, Hdac1/2, Sirt2, and Sirt6 were also found in SAMP8 under EE. Moreover, increased acetylation in $\mathrm{H} 3$ and $\mathrm{H} 4$ was found in the same experimental conditions [233].

A recent study showed a reduction in the gene expression of the chromatin regulator Rcor2 in SAMP8, which was found in reference to SAMR1. Reduced levels of Rcor2 complex increases inflammation in the SAMP8 strain by suppression of gene repression, such as Il-6, Ccl2, Ccl3, Cxcl5, Cxcllo, and Mpa2l [227].

The level of seven histone methylation sites, most located on histone H3 (H3K24, H3K27, H3K36, H3K79, H3R128, H4K20 and H2AR89), were found significantly decreased in the SAMP8 brain with respect to SAMR1 [242], providing evidence that posttranslational modification in SAMP8 is linked to senescence process.

It has been published that expression of Dnmt $3 b$ was increased in SAMP8 after injection of erythropoietin improving spatial learning and memory, indicating that the methylation state of DNA is necessary for learning and memory, including the memory formation [243]. Epigenetic mechanisms underlying cognitive impairment by accelerated aging in SAMP8 were also found in an AD mice model, as 5xFAD, where $A \beta$ is a key factor in cognitive impairment and neurodegeneration [233, 244].

It has been demonstrated that miRNAs also play an important role in the SAMP8 model [25], corroborating what has already been described concerning the role of miRNAs, both in development and in aging [245]. The first study demonstrated that miR-16 is underexpressed in the SAMP8 strain and that $m i R$ 16 reduces the protein levels of A $\beta P P$ [246]. Other authors demonstrated higher expression of miR-139 in the hippocampus of aged SAMP8 than in SAMR1. When miR-139 is overexpressed in SAMP8, the hippocampus-dependent learning and memory formation by modulating cannabinoid receptor type 2 (CB2) is impaired, whereas downregulation of $m i R$ 139 leads to an improvement in learning and memory [247].
Another study showed the abnormal expression of genes (nodes) of certain biological networks related to the AD patients were regulated by miRNAs such as $m i R-20 a ;-17,-34 a ;-155 ;-18 a ;-22 ;-26 a ;-101$; $-106 b$, and $-125 b$ and were found changed in SAMP8 in comparison with SAMR1 [248]. Furthermore, there are significant alterations in the expression of various genes of HDACs enzymes, such as Sirt1, Hdac5, and Hdac6, and also of the global levels of acetylation of histones $\mathrm{H} 3$ and $\mathrm{H} 4$ and of various miRNAs in the hippocampus in the SAMP8 female at 8 months of age, which partially revert with an intervention of voluntary exercise [25]. Finally, the use of the HDAC inhibitor, trichostatin, allowed the reversal of the senescent phenotype and DNA damage by increasing the levels of histone acetylation, and increasing the proliferation of exhausted NSC of SAMP8 in vitro [143].

In addition, a significant reduction in the expression of the miR-9 family in the SAMP8 strain compared to the age-matched SAMR1 control was found; this $m i R-9$ regulated in silico the genes PSEN1, $S C N 2 B, M A P 3 K 3$, and BACE1 [249]. This would explain in part the cognitive impairment and pathological process of SAMP8 mice model, confirming its relationship with aging and $\mathrm{AD}$.

Correlating the described modifications with cellular processes mentioned comprises a task that must be carried out in order to further demonstrate that miRNAs can control protein levels and in turn influence brain function and the cognitive abilities in SAMP8. The involvement of epigenetic modulation in the aging process, the neurodegeneration, and the central role of the gene regulation of miRNAs, could explain in part that the senescent phenotype found in the SAMP8 strain is an issue to be developed.

In sum, published results demonstrate the participation of epigenetic modulation in the aging and neurodegenerative processes, and the central role of gene regulation that miRNAs possess, explain in part the senescent phenotype that characterizes SAMP8.

\section{CONCLUSIONS}

Accumulating evidence proves that neurological disorders are closely related to the age and that neurodegenerative diseases are not an exception. The aging process, both in physiological and pathological conditions, as occurs in $\mathrm{AD}$, can be driven by epigenetic forces. Epigenetic changes are influenced by lifestyle (diet, exercise, smoking, etc.), by 
external environment factors (drugs, chemicals, etc.), and also by genetic inheritance. In the brain, any small change might induce disturbances that will lead to emotional imbalances, cognitive impairment, and neurodegeneration. The SAMP8 mice model has revealed cognitive and behavioral disturbances that occur at early age and that worsen with senescence. The accelerated senescence and, in particular, the cognitive impairment present in this murine model together with the epigenetic marker changes that are reviewed here, suggest this strain as a feasible option to reveal new targets and to study novel drugs to face harmful aging processes.

\section{ACKNOWLEDGMENTS}

This study was supported by Spanish MINECO (SAF2016-77703, CSD2010-00045), and the European Regional Development Funds, and 2017-SGR106 and the CERCA Programme from the Generalitat de Catalunya.

Authors' disclosures available online (https:// www.j-alz.com/manuscript-disclosures/17-0664r5).

\section{REFERENCES}

[1] Alzheimer's Association (2016) Alzheimer's disease facts and figures. Alzheimers Dement 12, 459-509.

[2] Brunet A, Berger L (2014) Epigenetics of aging and aging-related disease. J Gerontol A Biol Sci Med Sci 69, S17-S20

[3] Delgado-Morales R, Agís-Balboa RC, Esteller M, Berdasco M (2017) Epigenetic mechanisms during ageing and neurogenesis as novel therapeutic avenues in human brain disorders. Clin Epigenetics 9, 67.

[4] Mastroeni D, Grover A, Rogers J (2011) Epigenetics mechanisms in Alzheimer's disease. Neurobiol Aging 32, 1161-1180.

[5] López-Otín C, Blasco MA, Partridge L, Serrano M, Kroemer G (2013) The hallmarks of aging. Cell 153, 11941217.

[6] Mattsson N, Schott JM, Hardy J, Turner MR, Zetterberg $\mathrm{H}$ (2016) Selective vulnerability in neurodegeneration: Insights from clinical variants of Alzheimer's disease. J Neurol Neurosurg Psychiatry 87, 1000-1004.

[7] Grimm A, Friedland K, Eckert A (2016) Mitochondrial dysfunction: The missing link between aging and sporadic Alzheimer's disease. Biogerontology 17, 281-296.

[8] Grimm A, Ecker A (2017) Brain aging and neurodegeneration: From a mitochondrial point of view. J Neurochem 143, 418-431.

[9] Dubois B, Hampel H, Feldman HH, Scheltens P, Aisen P, Andrieu S, Bakardjian H, Benali H, Bertram L, Blennow K, Broich K, Cavedo E, Crutch S, Dartigues JF, Duyckaerts C, Epelbaum S, FRisoni GB, Gauthier S, Genthon R, Gouw AA, Habert MO, Holtzman DM, Kivipelto M, Lista S, Molinuevo JL, O’Bryant SE, Rabinovici GD,
Rowe C, Salloway S, Schneider LS, Sperling R, Teichmann M, Carrillo MC, Cummings J, Jack CR Jr (2016) Preclinical Alzheimer's disease: Definition, natural history, and diagnostic criteria. Alzheimers Dement 12, 292-323.

[10] Petersen KS, Smith C (2016) Ageing-associated oxidative stress and inflammation are alleviated by products from grapes. Oxid Med Cell Longev 2016, 6236309.

[11] Chakrabarti S, Mohanakumar KP (2016) Aging and neurodegeneration: A tangle of models and mechanisms. Aging Dis 7, 111-113.

[12] Hroudová J, Namrata S, Fišar Z (2014) Mitochondrial dysfunctions in neurodegenerative diseases: Relevance to Alzheimer's disease. Biomed Res Int 2014, 175062.

[13] Fivenson EM, Lautrup S, Sun N, Scheibye-Knudsen M, Stevnsner TV, Nilsen H, Bohr VA, Fang EF (2017) Mitophagy in neurodegeneration and aging. Neurochem Int 109, 202-209.

[14] Malhotra JD, Kaufman R (2011) ER stress and its functional link to mitochondria: Role in cell survival and death. Cold Spring Harb Perspect Biol 3, a004424.

[15] Plaza-Zabala A, Sierra-Torre V, Sierra A (2017) Autophagy and microglia: Novel partners in neurodegeneration and aging. Int J Mol Sci 18, pii: E598.

[16] Tanzi RE, Bertram L (2005) The genetic epidemiology of neurodegenerative disease. J Clin Invest 115, 1449-1457.

[17] Hardy J, Selkoe DJ (2002) The amyloid hypothesis of Alzheimer's disease: Progress and problems on the road to therapeutics. Science 297, 353-356.

[18] Hauptmann S, Keil U, Scherping I, Bonert A, Eckert A, Müller WE (2006) Mitochondrial dysfunction in sporadic and genetic Alzheimer's disease. Exp Gerontol 41, 668673.

[19] Folch J, Petrov D, Ettcheto M, Abad S, Sánchez-López E, García ML, Olloquequi J, Beas-Zarate C, Auladell C, Camins A (2016) Current research therapeutic strategies for Alzheimer's disease treatment. Neural Plast 2016, 8501693.

[20] Heneka MT, Carson MJ, El Kh oury J, Landreth GE, Brosseron F, Feinstein DL, Jacobs AH, Wyss-Coray T, Vitorica J, Ransohoff RM, Herrup K, Frautschy SA, Finsen B, Brown GC, Verkhratsky A, Yamanaka K, koistinaho J, Latz E, Halle A, Petzold GC, Town T, Morgan D, Shinohara ML, Perry VH, Homes C, Bazan NG, Brooks DJ, Hunot S, Joseph B, Deigendesch N, Garaschuk O, Boddeke E, Dinarello CA, Breither JC, Cole GM, Golenbock DT, Kummer MP (2015) Neuroinflammation in Alzheimer's disease. Lancet Neurol 14, 388-405.

[21] Colton CA, Mott RT, Sharpe H, Xu Q, Van Nostrand WE, Vitek MP (2006) Expression profiles for macrophage alternative activation genes in $\mathrm{AD}$ and in mouse models of $\mathrm{AD}$. J Neuroinflammation 3, 27.

[22] Russell DW, Smith M, Williamson VM, Young ET (1983) Nucleotide sequence of the yeast alcohol dehydrogenase II gene. J Biol Chem 258, 2674-2682.

[23] Weinstein G, Wolf PA, Beiser AS, Au R, Seshadri S (2013) Risk estimations, risk factors, and genetic variants associated with Alzheimer's disease in selected publications from the Framingham Heart Study. J Alzheimer Dis 33, S439-S445.

[24] Grant WB, Campbell A, Itzhaki RF, Savory J (2002) The significance of environmental factors in the etiology of Alzheimer's disease. J Alzheimers Dis 4, 179-189.

[25] Cosín-Tomás M, Alvarez-López MJ, Sanchez-Roige S, Lalanza JF, Bayod S, Sanfeliu C, Pallàs M, Escorihuela 
RM, Kaliman P (2014) Epigenetic alterations in hippocampus of SAMP8 senescent mice and modulation by voluntary physical exercise. Front Aging Neurosci 6, 51.

[26] Griffith JS, Mahler HR (1969) DNA ticketing theory of memory. Nature 223, 580-582.

[27] Riggs AD (1975) X inactivation, differentiation, and DNA methylation. Cytogenet Cell Genet 14, 9-25.

[28] Razin A, Riggs AD (1980) DNA methylation and gene function. Science 210, 604-610.

[29] Jaenisch R, Bird A (2003) Epigenetic regulation of gene expression: How the genome integrates intrinsic and environmental signals. Nat Genet 33, 245-254.

[30] Jakovceski M, Akbarian S (2012) Epigenetic mechanisms in neurological disease. Nat Med 18, 1194-1204.

[31] Zovkic IB, Guzman-Karlsson MC, Sweatt JD (2013) Epigenetic regulation of memory formation and maintenance. Learn Mem 20, 61-74.

[32] Bird A (2002) DNA methylation patterns and epigenetic memory. Genes Dev 16, 6-21.

[33] Strichman-Almashanu LZ, Lee RS, Onyango PO, Perlman E, Flam F, Frieman MB, Feinberg AP (2002) A genomewide screen for normally methylated human cpg islands that can identify novel imprinted genes. Genome Res 12, 543-554.

[34] Li E, Beard C, Jaenisch R (1993) Role for DNA methylation in genomic imprinting. Nature 366, 362-365.

[35] Chen ZX, Riggs AD (2011) DNA methylation and demethylation in mammals. J Biol Chem 286, 1834718353.

[36] Cedar H, Bergman Y (2009) Linking DNA methylation and histone modification: Patterns and paradigms. Nat Rev Genet 10, 295-304.

[37] Hata K, Okano M, Lei H, Li E (2002) Dnmt3L cooperates with the Dnmt3 family of de novo DNA methyltransferases to establish maternal imprints in mice. Development 129, 1983-1993.

[38] Bestor TH (2000) The DNA methyltransferases of mammals. Hum Mol Genet 9, 2395-2402.

[39] Hermann A, Gowher H, Jeltsch A (2004) Biochemistry and biology of mammalian DNA methyltransferases. Cell Mol Life Sci 61, 2571-2587.

[40] Münzel M, Lischke U, Stathis D, Pfaffeneder T, Gnerlich FA, Deiml CA, Koch SC, Karaghiosoff K, Carell $\mathrm{T}$ (2011) Improved synthesis and mutagenicity of oligonucleotides containing 5-hydroxymethylcytosine, 5formylcytosine and 5-carboxyl-cytosine. Chem Eur J 17, 13782-13788.

[41] Globisch D, Münzel M, Müller M, Michalakis S, Wagner M, Koch S, Brückl T, Biel M, Carell T (2010) Tissue distribution of 5-hydroxymethylcytosine and search for active demethylation intermediates. PLoS One 5, e15367.

[42] Tahiliani M, Koh KP, Shen Y, Pastor WA, Bandukwala H, Brudno Y, Agarwal S, Iyer LM, Liu DR, Aravind L, Rao A (2009) Conversion of 5-methylcytosine to 5hydroxymethylcytosine in mammalian DNA by MLL partner TET1. Science 324, 930-935.

[43] Ficz G, Branco MR, Seisenberger S, Santos F, Krueger F, Hore TA, Marques CJ, Andrews S, Reik W (2011) Dynamic regulation of 5-hydroxymethylcytosine in mouse ES cells and during differentiation. Nature 473, 398-402.

[44] Huang Y, Chavez L, Chang X, Wang X, Pastor WA, Kang J, Zepeda-Martínez JA, Pape UJ, Jacobsen SE, Peters B, Rao A (2014) Distinct roles of the methylcytosine oxidases Tet 1 and Tet 2 in mouse embryonic stem cells. Proc Natl Acad Sci U S A 111, 1361-1366.
[45] Gu T-P, Guo F, Yang H, Wu H-P, Xu GF, Liu W, Xie ZG, Shi L, He X, Jin SG, Iqbal K, Shi YG, Deng Z, Szabó PE, Pfeifer GP, Li J, Xu GL (2011) The role of Tet3 DNA dioxygenase in epigenetic reprogramming by oocytes. Nature 477, 606-610.

[46] Zentner GE, Henikoff S (2013) Regulation of nucleosome dynamics by histone modifications. Nat Struct Mol Biol 20, 259-266.

[47] Tessarz P, Kouzarides T (2014) Histone core modifications regulating nucleosome structure and dynamics. Nat Rev Mol Cell Biol 15, 703-708.

[48] Konsoula Z, Barile FA (2012) Epigenetic histone acetylation and deacetylation mechanisms in experimental model of neurodegenerative disorders. J Pharmacol Toxicol Methods 66, 215-220.

[49] Sengupta N, Seto E (2004) Regulation of histone deacetylase activities. J Cell Biochem 93, 57-67.

[50] Turner B (2001) Chromatin and gene regulation. Blackwell Science Ltd., Oxford.

[51] Xu WS, Parmigiani RB, Marks PA (2007) Histone deacetylase inhibitors: Molecular mechanisms of action. Oncogene 26, 5541-5552.

[52] Wade C, Shea KA, Jensen RV, McAlear MA (2001) EBP2 is a member of the yeast $\mathrm{RRB}$ regulon, a transcriptionally coregulated set of genes that are required for ribosome and rRNA biosynthesis. Mol Cell Biol 21, 8638-8650.

[53] Ruijter AJM, van Gennip AH, Caron HN, Kemp S, van Kuilenburg ABP (2003) Histone deacetylases (HDACs): Characterization of the classical HDAC family. Biochem $J$ 370(Pt 3), 737-749.

[54] Delcuve GP, Khan DH, Davie JR (2012) Roles of histone deacetylases in epigenetic regulation: Emerging paradigms from studies with inhibitors. Clin Epigenetics 4,5 .

[55] Greer EL, Shi Y (2012) Histone methylation: A dynamic mark in health, disease and inheritance. Nat Rev Genet 13, 343-357.

[56] Herskovits AZ, Guarente L (2014) SIRT1 in neurodevelopment and brain senescence. Neuron 81, 471-483.

[57] Lalla R, Donmez G (2013) The role of sirtuins in Alzheimer's disease. Front Aging Neurosci 5, 16.

[58] Haigis MC, Sinclair DA (2010) Mammalian sirtuins: Biological insights and disease relevance. Annu Rev Pathol 5, 253-295.

[59] Cheung P, Allis CD, Sassone-Corsi P (2000) Signaling to chromation through histone modifications. Cell 103, 263-271.

[60] Grant PA (2001) A tale of histone modifications. Genome Biol 2, REVIEWS0003.

[61] Rossetto D, Avvakumov N, Côté J (2012) Histone phosphorylation: A chromatin modification involved in diverse nuclear events. Epigenetics 7, 1098-1108.

[62] Wen KX, Miliç J, El-Khodor B, Dhana K, Nano J, Pulido T, Kraja B, Zaciragic A, Bramer WM, Troup J, Chowdhury R, Ikram MA, Dehghan A, Muka T, Franco OH (2016) The role of DNA methylation and histone modifications in neurodegenerative diseases: A systematic review. PLoS One 11, e0167201.

[63] Morceau F, Chateauvieux S, Gaigneaux A, Dicato M, Diederich M. (2013) Long and short non-coding RNAs as regulators of hematopoietic differentiation. Int $\mathrm{J} \mathrm{Mol}$ Sci 14, 14744-14770.

[64] Wilusz JE, Sunwoo H, Spector DL (2009) Long noncoding RNAs: Functional surprises from the RNA world. Genes Dev 23, 1494-1504. 
[65] Wahid F, Shehzad A, Khan T, Kim YY (2010) MicroRNAs: Synthesis, mechanism, function, and recent clinical trials. Biochim Biophys Acta 1803, 1231-1243.

[66] Griffiths-Jones S (2014) miRBase: The microRNA database. http://www.mirbase.org, Last update Jul 3, 2104.

[67] Brennecke J, Stark A, Russell RB, Cohen SM (2005) Principles of MicroRNA-target recognition. PLoS Biol 3, e85.

[68] Catalanotto C, Cogoni C, Zardo G (2016) MicroRNA in control of gene expression: An overview of nuclear functions. Int J Mol Sci 17, 1712.

[69] Lee RC, Feinbaum RL, Ambros V (1993) The C. elegans heterochronic gene lin-4 encodes small RNAs with antisense complementarity to lin- 14. Cell 75, 843-854.

[70] Chawla G, Sokol NS (2011) MicroRNAs in Drosophila development. Int Rev Cell Mol Biol 286, 1-65.

[71] Song L, Tuan RS (2006) MicroRNAs and cell differentiation in mammalian development. Birth Defects Res $C$ Embryo Today 78, 140-149.

[72] Wienholds E, Plasterk RH (2005) MicroRNA function in animal development. FEBS Lett 579, 5911-5922.

[73] Maciotta S, Meregalli M, Torrente Y (2013) The involvement of microRNAs in neurodegenerative diseases. Front Cell Neurosci 7, 265.

[74] Romaine SP, Tomaszewski M, Condorelli G, Samani NJ (2015) MicroRNAs in cardiovascular disease: An introduction for clinicians. Heart 101, 921-928.

[75] Tang X, Tang G, Ozcan S (2008) Role of microRNAs in diabetes. Biochim Biophys Acta 1779, 697-701.

[76] Hauberg ME, Holm-Nielsen MH, Mattheisen M, Askou AL, Grove J, Børglum AD, Corydon TJ (2016) Schizophrenia risk variants affecting microRNA function and site-specific regulation of NT5C 2 by miR-206. Eur Neuropsychopharmacol 26, 1522-1526.

[77] Chen W, Qin C (2015) General hallmarks of microRNAs in brain evolution and development. RNA Biol 12, 701-708.

[78] Murr R (2010) Interplay between different epigenetic modifications and mechanisms. Adv Genet 70, 101-141.

[79] Yoo AS, Staahl BT, Chen L, Gerald R, Crabtree (2009) MicroRNA-mediated switching of chromatin-remodelling complexes in neural development. Nature 460, 642-646.

[80] Spiegel AM, Sewal AS, Rapp PR (2014) Epigenetic contributions to cognitive aging: Disentangling mindspan and lifespan. Learn Mem 21, 569-574.

[81] Rowbotham DA, Marshall EA, Vucic EA, Kennett JY, Lam WL, Martinez VD (2015) Epigenetic changes in aging and age-related disease. JASC 3, 130.

[82] Sierra MI, Fernández AF, Fraga MF (2015) Epigenetics of aging. Curr Genomics 16, 435-440.

[83] Lepeule J, Baccarelli A, Motta V, Cantone L, Litonjua AA, Sparrow D, Vokonas PS, Schwartz J (2012) Gene promoter methylation is associated with lung function in the elderly: The Normative Aging Study. Epigenetics 7, 261-269.

[84] Feser J, Tyler J (2011) Chromatin structure as a mediator of aging. FEBS Lett 585, 2041-2048.

[85] Artal-Martinez de Narvajas A, Gomez TS, Zhang JS, Mann AO, Taoda Y, Gorman JA, Herreros-Villanueva M, Gress TM, Ellenrieder V, Bujanda L, Kim DH, Kozikowski AP, Koenig A, Billadeau DD (2013) Epigenetic regulation of autophagy by the methyltransferase G9a. Mol Cell Biol 33, 3983-3993.

[86] Akbarian S, Beeri MS, Haroutunian V (2013) Epigenetic determinants of healthy and diseased brain aging and cognition. JAMA Neurol 70, 711-718.
[87] Haggarty SJ, Tsai LH (2011) Probing the role of HDACs and mechanisms of chromatin-mediated neuroplasticity. Neurobiol Learn Mem 96, 41-52.

[88] Muñoz-Najar U, Sedivy JM (2011) Epigenetic control of aging. Antioxid Redox Signal 14, 241-259.

[89] Hing B, Gardner C, Potash JB (2014) Effects of negative stressors on DNA methylation in the brain: Implications for mood and anxiety disorders. Am J Med Genet B Neuropsychiatr Genet 165B 541-554.

[90] Morris MJ, Monteggia LM (2014) Role of DNA methylation and the DNA methyltransferases in learning and memory. Dialogues Clin Neurosci 16, 359-371.

[91] LaPlant Q, Vialou V, Covington HE III, Dumitriu D, Feng J, Warren BL, Maze I, Dietz DM, Watts EL, Iñiguez SD, Koo JW, Mouzon E, Renthal W, Hollis F, Wang H, Noonan M, Ren Y, Eisch AJ, Bolaós CA, Kabbaj M, Xiao G, Neve RL, Hurd YL, Oosting RS, Fan G (2010) Dnmt3a regulates emotional behavior and spine plasticity in the nucleus accumbens. Nat Neurosci 13, 1137-1143.

[92] Kramer JM, Kochinke K, Oortveld MA, Marks H, Kramer D, de Jong EK, Asztalos Z, Westwood JT, Stunnenberg HG, Sokolowski MB (2011) Epigenetic regulation of learning and memory by Drosophila EHMT/G9a. PLoS Biol 9, e1000569.

[93] McQuown SC, Barrett RM, Matheos DP, Post RJ, Rogge GA, Alenghat T, Mullican SE, Jones S, Rusche JR, Lazar MA, Wood MA (2011) HDAC3 is a critical negative regulator of long-term memory formation. J Neurosci $\mathbf{3}$, 764-777.

[94] Guan JS, Haggarty SJ, Giacometti E, Dannenberg JH, Joseph N, Gao J, Nieland TJ, Zhou Y, Wang X, Mazitschek R, Bradner JE, DePinho RA, Jaenisch R, Tsai LH (2009) HDAC2 negatively regulates memory formation and synaptic plasticity. Nature 459, 55-60.

[95] Oliveira AMM, Hemstedt TJ, Bading H (2012) Rescue of aging-associated decline in Dnmt3a2 expression restores cognitive abilities. Nat Neurosci 15, 1111-1113.

[96] Miller CA, Gavin CF, White JA, Parrish RR, Honasoge A, Yancey CR, Rivera IM, Rubio MD, Rumbaugh G, Sweatt JD (2010) Cortical DNA methylation maintains remote memory. Nat Neurosci 13, 664-666.

[97] Feng S, Cokus SJ, Zhang X, Chen PY, Bostick M, Goll MG, Hetzel J, Jain J, Strauss SH, Halpern ME, Ukomadu C, Sadler KC, Pradhan S, Pellegrini M, Jacobsen SE (2010) Conservation and divergence of methylation patterning in plant and animals. Proc Natl Acad Sci U S A 107, 8689-8694.

[98] Guo JU, Ma DK, Mo H, Ball MP, Jang MH, Bonaguidi MA, Balazer JA, Eaves HL, Xie B, Ford E, Zhang K, Ming GL, Gao Y, Song H (2011) Neuronal activity modifies the DNA methylation landscape in the adult brain. Nat Neurosci 14, 1345-1351.

[99] Levenson JM, Roth TL, Lubin FD, Miller CA, Huang IC, Desai P, Malone LM, Sweatt JD (2006) Evidence that DNA (cytosine-5) methyltransferase regulates synaptic plasticity in the hippocampus. J Biol Chem 281, 1576315773.

[100] West RL, Lee JM, Maroun LE (1995) Hypomethylation of the amyloid precursor protein gene in the brain of an Alzheimer's disease patient. J Mol Neurosci 6, 141.

[101] Gonzalo S (2010) Epigenetic alterations in aging. J Appl Physiol (1985) 109, 586-597.

[102] De Haan G, Gerrits A (2007) Epigenetic control of hematopoietic stem cell aging the case of Ezh2. Ann $N$ Y Acad Sci 1106, 233-239. 
[103] Javan SV, Maddalena A, Kerimoglu C, Wittnam J, Held T, BährM, Burkhardt S, Delalle I, Kügler S, Fischer A, Sananbenesi F (2012) HDAC1 regulates fear extinction in mice. J Neurosci 32, 5062-5073.

[104] Sharma S, Taliyan R, Ramagiri S (2015) Histone deacetylase inhibitor, trichostatin A, improves learning and memory in high-fat diet-induced cognitive deficits in mice. J Mol Neurosci 56, 1-11.

[105] Haettig J, Stefanko DP, Multani ML, Figueroa DX, McQuown SC, Wood MA (2011) HDAC inhibiton modulates hippocampus-dependent long-term memory for object location in a CBP-dependent manner. Learn Mem 18, 71-79.

[106] Yoo DY, Kim DW, Kim MJ, Choi JH, Jung HY, Nam SM, Kim JW, Yoon YS, Choi SY, Hwang IK (2015) Sodium butyrate, a histone deacetylase Inhibitor, ameliorates SIRT2-induced memory impairment, reduction of cell proliferation, and neuroblast differentiation in the dentate gyrus. Neurol Res 37, 69-75.

[107] Liao CY, Kennedy BK (2016) SIRT6, oxidative stress, and aging. Cell Res 26, 143-144.

[108] Corpas R, Revilla S, Ursulet S, Castro-Freire M, Kaliman P, Petegnief V, Giménez-Llort L, Sarkis C, Pallàs M, Sanfeliu C (2016) SIRT1 overexpression in mouse hippocampus induces cognitive enhancement. Mol Neurobiol 54, 5604-5619.

[109] Lee HR, Shin HK, Park SY, Kim HY, Lee WS, Rhim BY, Hong KW, Kim CD (2014) Cilostazol suppresses $\beta$-amyloid production by activating a disintegrin and metalloproteinase 10 via the upregulation of SIRT1coupled retinoic acid receptor- $\beta$. J Neurosci Res 92, 1581-1590.

[110] Min SW, Cho SH, Zhou Y, Schroeder S, Haroutunian V, Seeley WW, Huang EJ, Shen Y, Masliah E, Mukherjee C, Meyers D, Cole PA, Ott M, Gan L (2010) Acetylation of tau inhibits its degradation and contributes to tauopathy. Neuron 67, 953-966.

[111] Cardinale A, de Stefano MC, Mollinari C, Racaniello M, Garaci E, Merlo D (2015) Biochemical characterization of sirtuin 6 in the brain and its involvement in oxidative stress response. Neurochem Res 40, 59-69.

[112] Volmar CH, Wahlestedt C (2015) Histone deacetylases (HDACs) and brain function. Neuroepigenetics 1, 20-27.

[113] Pal S, Tyler JK (2016) Epigenetics and aging. Sci Adv 2, e1600584.

[114] Pasyukova EG, Vaiserman AM (2017) HDAC inhibitors: A new promising drug class in anti-aging research. Mech Ageing Dev 166, 6-15.

[115] Ludwig N, Leidinger P, Becker K, Backes C, Fehlmann T, Pallasch C, Rheinheimer S, Meder B, Stähler C, Meese E, Keller A (2016) Distribution of miRNA expression across human tissues. Nucleic Acids Res 44, 3865-3877.

[116] Smith-Vikos T, Slack FJ (2012) MicroRNAs and their roles in aging. J Cell Sci 125, 7-17.

[117] Faraonio R, Salerno P, Passaro F, Sedia C, Iaccio A, Bellelli R, Nappi TC, Comegna M, Romano S, Salvatore G, Santoro M, Cimino F (2012) A set of miRNAs participates in the cellular senescence program in human diploid fibroblasts. Cell Death Diff 19, 713-721.

[118] Persengiev SP, Kondova II, Bontrop RE (2012) The impact of microRNAs on brain aging and neurodegeneration. Curr Gerontol Geriatr Res 2012, 359369.

[119] Kuhn DE, Martin MM, Feldman DS, Terry AV, Nuovo GJ, Elton TS (2008) Experimental validation of miRNA targets. Methods 44, 47-54.
[120] Inukai S, de Lencastre A, Turner M, Slack F (2012) Novel microRNAs differentially expressed during aging in the mouse brain. PLoS One 7, e40028.

[121] Xu S, Zhang R, Niu J, Cui D, Xie B, Zhang B, Lu K, Yu W, Wang X, Zhang Q (2012) Oxidative stress mediatedalterations of the microRNA expression profile in mouse hippocampal neurons. Int J Mol Sci 13, 16945-16960.

[122] Danka Mohamed CP, Park JS, Nam HG, Kim K (2017) MicroRNAs in brain aging. Mech Ageing Dev 168, 3-9.

[123] Dovkic IB, Guzman-Karlsson MC, Sweatt JD (2013) Epigenetic regulation of memory formation and maintenance. Learn Mem 20, 61-74.

[124] Lagos-Quintana M, Rauhut R, Yalcin A, Meyer J, Lendeckel W, Tuschl T (2002) Identification of tissuespecific microRNAs from mouse. Curr Biol 12, 735.

[125] Hébert SS, Horré K, Nicolai L, Papadopoulou AS, Mandemakers W, Silahtaroglu AN Kauppinen S, Delacourte A, Strooper BD (2008) Loss of microRNA cluster miR29a/b-1 in sporadic Alzheimer's disease correlates with increased BACE1/beta-secretase expression. Proc Nat Acad Sci U S A 105, 6415-6416.

[126] Tohgi H, Utsugisawa K, Nagane Y, Yoshimura M, Genda Y, Ukitsu M (1999) Reduction with age in methylcytosine in the promoter region -224 approximately -101 of the amyloid precursor protein gene in autopsy human cortex. Brain Res Mol Brain Res 70, 288-292.

[127] Xu X (2015) DNA methylation and cognitive aging. Oncotarget 6, 13922-13932.

[128] Castellani CA, Laufer BI, Melka MG, Diehl EJ, O'Reilly RL, Singh SM (2015) DNA methylation differences in monozygotic twin pairs discordant for schizophrenia identifies psychosis related genes and networks. BMC Med Genomics 8, 17.

[129] Maloney B, Sambamurti K, Zawia N, Lahiri DK (2012) Applying epigenetics to Alzheimer's disease via the latent early-life associated regulation (LEARn) model. Curr Alzheimer Res 9, 589-599.

[130] Fuso A, Nicolia V, Pasqualato A, Fiorenza MT, Cavallaro RA, Scarpa S (2011) Changes in Presenilin 1 gene methylation pattern in diet-induced B vitamin deficiency. Neurobiol Aging 32, 187-199.

[131] Bayarsaihan D (2011) Epigenetic mechanisms in inflammation. J Dent Res Jan 90, 9-17.

[132] Sawicka A, Seiser C (2012) Histone H3 phosphorylation a versatile chromatin modification for different occasions. Biochimie 94, 2193-2201.

[133] Mori T, Wakabayashi T, Ogawa H, Hirahara Y, Koike T, Yamada H (2013) Increased histone H3 phosphorylation in neurons in specific brain structures after induction of status epilepticus in mice. PLoS One 8, e77710.

[134] Hu YB, Li CB, Song N, Zou Y, Chen SD, Ren RJ, Wang G (2016) Diagnostic value of microRNA for Alzheimer's disease: A systemic review and meta-analysis. Front Aging Neurosci 8, 13.

[135] Drummond E, Wisniewski T (2017) Alzheimer's disease: Experimental models and reality. Acta Neuropathol 133, 155-175.

[136] Esquerda-Canals G, Montoliu-Gaya L, Güell-Bosch J, Villegas S (2017) Mouse models of Alzheimer's disease. J Alzheimers Dis 57, 1171-1183.

[137] Chan ES, Shetty MS, Sajikumar S, Chen C, Soong TW, Wong B-S (2016) ApoE4 expression accelerates hippocampus-dependent cognitive deficits by enhancing $\mathrm{A} \beta$ impairment of insulin signaling in an Alzheimer's disease mouse model. Sci Rep 6, 26119. 
[138] Woodruff-Pak DS (2008) Animal models of Alzheimer's disease: Therapeutic implications. J Alzheimers Dis 15, 507-521.

[139] Pallàs M, Camins A, Smith MA, Perry G, Lee HG, Casadesus G (2008) From aging to Alzheimer's disease: Unveiling "the switch" with the senescence-accelerated mouse model (SAMP8). J Alzheimers Dis 15, 615-624.

[140] Takeda T (1999) Senescence-accelerated mouse (SAM): A biogerontological resource in aging research. Neurobiol Aging 20, 105-110.

[141] Flood JF, Morley JE (1998) Learning and memory in the SAMP8 mouse. Neurosci Biobehav Rev 22, 1-20.

[142] Akiguchi I, Pallàs $M$, Budka $H$, Akiyama $H$, Ueno $M$, Han J, Yagi H, Nishikawa T, Chiba Y, Sugiyama H, Takahashi R, Unno K, Higuchi K, Hosokawa M (2017) SAMP8 mice as a neuropathological model of accelerated brain aging and dementia: Toshio Takeda's legacy and future directions. Neuropathology 37, 293-305.

[143] Soriano-Cantón R, Perez-Villalba A, Morante-Redolat JM, Marqués-Torrejón MÁ, Pallás M, Pérez-Sánchez F, Fariñas I (2015) Regulation of the p19 (Arf)/p53 pathway by histone acetylation underlies neural stem cell behavior in senescence-prone SAMP8 mice. Aging Cell 14, 453462.

[144] Takeda T (2009) Senescence-accelerated mouse (SAM) with special references to neurodegeneration models, SAMP8 and SAMP10 mice. Neurochem Res 34, 639-659.

[145] Cheng XR, Zhou WX, Zhang YX (2014) The behavioral, pathological and therapeutic features of the senescenceaccelerated mouse prone 8 strain as an Alzheimer's disease animal model. Ageing Res Rev 13, 13-37.

[146] Markowska AL, Spangler EL, Ingram DK (1998) Behavioral assessment of the senescence-accelerated mouse (SAM P8 and R1). Physiol Behav 64, 15-26.

[147] Takeda T, Hosokawa M, Higuchi K (1994) Senescenceaccelerated mouse (SAM): A novel murine model of aging. In The SAM Model of Senescence, Takeda, T, ed. Elsevier Science, Amsterdam, pp. 15-22.

[148] Porquet D, Casadesús G, Bayod S, Vicente A, Canudas AM, Vilaplana J, Pelegrí C, Sanfeliu C, Camins A, Pallàs M, del Valle J (2013) Dietary resveratrol prevents Alzheimer's markers and increases life span in SAMP8. Age 35, 1851-1865.

[149] Flood JF, Farr SA, Kaiser FE, Morley JE (1995) Agerelated impairment in learning but not memory in SAMP8 female mice. Pharmacol Biochem Behav 50, 661-664.

[150] Ito K, Ahadieh S, Corrigan B, French J, Fullerton T, Tensfeldt T (2009) Disease progression meta-analysis model in Alzheimer's disease. Alzheimers Dement 6, 39-53.

[151] Miyamoto M, Kiyota Y, Yamazaki N, Nagaoka A, Matsuo T, Nagawa Y, Takeda T (1986) Age-related changes in learning and memory in the senescence- accelerated mouse (SAM). Physiol Behav 38, 399-406.

[152] Ikegami S, Shumiya S, Kawamura H (1992) Age-related changes in radial-arm maze learning and basal forebrain cholinergic Systems in senescence accelerated maze (SAM). Behav Brain Res 51, 15-22.

[153] Maurice T, Lockhart BP, Privat A (1996) Amnesia induced in mice by centrally administered beta-amyloid peptides involves cholinergic dysfunction. Brain Res 706, 181193.

[154] Molinuevo JL, Cami J, Carné X, Carrillo MC, Georges J, Isaac MB, Khachaturian Z, Kim SY, Morris JC, Pasquier F, Ritchie C, Sperling R, Karlawish J (2016) Ethical challenges in preclinical Alzheimer's disease observa- tional studies and trials: Results of the Barcelona Summit. Alzheimers Dement 12, 614-622.

[155] Sperling R, Mormino E, Johnson K (2014) The evolution of preclinical Alzheimer's disease: Implications for prevention trials. Neuron 84, 608-622.

[156] Chen GH, Wang YJ, Wang XM, Zhou JN (2004) Accelerated senescence prone mouse- 8 shows early onset of deficits in spatial learning and memory in the radial sixarm water maze. Physiol Behav 82, 883-890.

[157] Hwang JH, Lee IT, Jeng KC, Wang MF, Hou RC, Wu SM, Chan YC (2011) Spirulina prevents memory dysfunction, reduces oxidative stress damage and augments antioxidant activity in senescence-accelerated mice. $J$ Nutr Sci Vitaminol 57, 186-191.

[158] López-Ramos JC, Jurado-Parras MT, Sanfeliu C, AcuñaCastroviejo D, Delgado-García JM (2012) Learning capabilities and CA1-prefrontal synaptic plasticity in a mice model of accelerated senescence. Neurobiol Aging 33, 13-26.

[159] Zhang X, Li G, Guo L, Nie K, Jia Y, Zhao L, Yu J (2013) Age-related alteration in cerebral blood flow and energy failure is correlated with cognitive impairment in the senescence-accelerated prone mouse strain 8 (SAMP8). Neurol Sci 34, 1917-1924.

[160] Sawano E, Negishi T, Aoki T, Murakami M, Tashiro T (2013) Alterations in local thyroid hormone signaling in the hippocampus of the SAMP8 mouse at younger ages: Association with delayed myelination and behavioral abnormalities. J Neurosci Res 91, 382-392.

[161] Yanai S, Endo S (2016) Early onset of behavioral alterations in senescence-accelerated mouse prone 8 (SAMP8). Behav Brain Res 308, 187-195.

[162] Morley JE, Farr SA, Kumar VB, Armbrecht HJ (2012) The SAMP8 mouse: A model to develop therapeutic interventions for Alzheimer's disease. Curr Pharm Des 18, 1123-1130.

[163] Yagi H, Katoh S, Akiguchi I, Takeda T (1988) Age-related deterioration of ability of acquisition in memory and learning in senescence accelerated mouse: SAM-P/8 as an animal model of disturbances in recent memory. Brain Res 474, 86-93.

[164] Spangler EL, Patel N, Speer D, Hyman M, Hengemihle J, Markowska A, Ingram DK (2002) Passive avoidance and complex maze learning in the senescence accelerated mouse (SAM): Age and strain comparisons of SAM P8 and R1. J Gerontol A Biol Sci Med Sci 57, B61-B68.

[165] Wang F, Chen H, Sun X (2009) Age-related spatial cognitive impairment is correlated with a decrease in ChAT in the cerebral cortex, hippocampus and forebrain of SAMP8 mice. Neurosci Lett 454, 212-217.

[166] Miyamoto M, Kiyota Y, Nishiyama M, Nagaoka A (1992) Senescence-accelerated mouse (SAM): Agerelated reduced anxiety-like behavior in the SAM-P/8 strain. Physiol Behav 51, 979-985.

[167] Pérez-Cáceres D, Ciudad-Roberts A, Rodrigo MT, Pubill D, Camins A, Camarasa J, Escubedo E, Pallàs M (2013) Depression-like behavior is dependent on age in male SAMP8 mice. Biogerontology 14, 165-176.

[168] Meeker HC, Chadman KK, Heaney AT, Carp RI (2013) Assessment of social interaction and anxiety-like behavior in senescence-accelerated-prone and -resistant mice. Physiol Behav 118, 97-102.

[169] García-Mesa Y, López-Ramos JC, Giménez-Llort L, Revilla S, Guerra R, Gruart A, Laferla FM, Cristòfol R, Delgado-García JM, Sanfeliu C (2011) Physical exercise 
protects against Alzheimer's disease in $3 \mathrm{xTg}-\mathrm{AD}$ mice. J Alzheimers Dis 24, 421-454.

[170] Takeuchi T, Duszkiewicz AJ, Morris RG (2014) The synaptic plasticity and memory hypothesis: Encoding, storage and persistence. Philos Trans R Soc Lond B Biol Sci 369, 20130288.

[171] Lin N, Pan XD, Chen AQ, Zhu YG, Wu M, Zhang J, Chen XC (2014) Tripchlorolide improves age-associated cognitive deficits by reversing hippocampal synaptic plasticity impairment and NMDA receptor dysfunction in SAMP8 mice. Behav Brain Res 258, 8-18.

[172] Pérez-Cañamás A, Sarroca S, Melero-Jerez C, Porquet D, Sansa J, Knafo S, Esteban JA, Sanfeliu C, Ledesma MD (2016) A diet enriched with plant sterols prevents the memory impariment induced by cholesterol loss in senescence-accelerated mice. Neurobiol Aging 48, 1-12.

[173] Taniguchi S, Mizuno H, Kuwahara M, Ito K (2015) Early attenuation of long-term potentiation in senescenceaccelerated mouse prone 8. Exp Brain Res 233, 31453152.

[174] Dobarro M, Orejana L, Aguirre N, Ramírez MJ (2013) Propanolol restores cognitive deficits and improves amyloid and Tau pathologies in a senescence-accelerated mouse model. Neuropharmacology 64, 137-144.

[175] Li Q, Zhao HF, Zhang ZF, Liu ZG, Pei XR, Wang JB, Li Y (2009) Long-term green tea catechin administration prevents spatial learning and memory impairment in senescence- accelerated mouse prone- 8 mice by decreasing Abeta1-42 oligomers and upregulating synaptic plasticity-related proteins in the hippocampus. Neuroscience 163, 741-749.

[176] Miyazaki H, Okuma Y, Nomura J, Nagashima K, Nomura $\mathrm{Y}$ (2003) Age-related alterations in the expression of glial cell line-derived neurotrophic factor in senescenceaccelerated mouse brain. J Pharmacol Sci 92, 28-34.

[177] Revilla S, Ursulet S, Álvarez-López MJ, Castro-Freire M, Perpiñá U, García-Mesa Y, Bortolozzi A, Giménez-Llort L, Kaliman P, Cristòfol R, Sarkis C, Sanfeliu C (2014) Lenti-GDNF gene therapy protects against Alzheimer's disease-like neuropathology in 3xTg-AD mice and MC65 cells. CNS Neurosci Ther 20, 961-972.

[178] Tajes M, Gutierrez-Cuesta J, Folch J, Ortuño-Sahagun D, Verdaguer E, Jiménez A, Junyent F, Lau A, Camins A, Pallàs M (2010) Neuroprotective role of intermittent fasting in senescence-accelerated mice P8 (SAMP8). Exp Gerontol 45, 702-710.

[179] Corpas R, Hernández-Pinto AM, Porquet D, HernándezSánchez C, Bosch C, Ortega-Aznar A, Comellas F, de la Rosa E, Sanfeliu C (2017) Proinsulin protects against age-related cognitive loss through anti-inflammatory convergent pathways. Neuropharmacology 123, 221-232.

[180] Palomer E, Martín-Segura A, Baliyan S, Ahmed T, Balschun D, Venero C, Martin MG, Dotti CG (2016) Aging triggers a repressive chromatin state at BDNF promoters in hippocampal neurons. Cell Rep 16, 2889-2900.

[181] Connor B, Young D, Yan Q, Faull RL, Synek B, Dragunow M (1997) Brain-derived neurotrophic factor is reduced in Alzheimer's disease. Brain Res Mol Brain Res 49, 71-81.

[182] Amada N, Aihara K, Ravid R, Horie M (2005) Reduction of NR1 and phosphorylated $\mathrm{Ca} 2+/$ calmodulin-dependent protein kinase II levels in Alzheimer's disease. Neuroreport 16, 1809-1813.

[183] Chang TY, Yamauchi Y, Hasan M, Chang CC (2017) Cellular cholesterol homeostasis in Alzheimer's disease. J Lipid Res 58, 2239-2254.
[184] Griñán-Ferré C, Palomera-Avalos V, Puigoriol-Illamola D, Camins A, Porquet D, Plá V, Aguado F, Pallàs M (2016) Behaviour and cognitive changes correlated with hippocampal neuroinflammaging and neuronal markers in female SAMP8, a model of accelerated senescence. Exp Gerontol 80, 57-69.

[185] Morley JE, Kumar VB, Bernardo AE, Farr SA, Uezu K, Tumosa N, Flood JF (2000) Beta-amyloid precursor polypeptide in SAMP8 mice affects learning and memory. Peptides 21, 1761-1767.

[186] Kumar VB, Franko M, Banks WA, Kasinadhuni P, Farr SA, Vyas K, Choudhuri V, Morley JE (2009) Increase in presenilin 1 (PS1) levels in senescence-accelerated mice (SAMP8) may indirectly impair memory by affecting amyloid precursor protein (APP) processin. $J$ Exp Biol 212(Pt4), 494-498.

[187] Banks WA, Kumar VB, Farr SA, Nakaoke R, Robinson SM, Morley JE (2011) Impairments in brain-to-blood transport of amyloid-( and reabsorption of cerebrospinal fluid in an animal model of Alzheimer's disease are reversed by antisense directed against amyloid- $\beta$ protein precursor. J Alzheimers Dis 23, 599-605.

[188] Armbrecht HJ, Siddiqui AM, Green M, Farr SA, Kumar VB, Banks WA, Patrick P, Shah GN, Morley JE (2015) Antisense against amyloid-( protein precursor reverses memory deficits and alters gene expression in neurotropic and insulin-signaling pathways in SAMP8 mice. J Alzheimers Dis 46, 535-548.

[189] Xu G, Ran Y, Fromholt SE, Fu C, Yachnis AT, Golde TE, Borchelt DR (2015) Murine A( over-production produces diffuse and compact Alzheimer-type amyloid deposits. Acta Neuropathol Commun 3, 72.

[190] Takemura M, Nakamura S, Akiguchi I, Ueno M, Oka N, Ishikawa S, Shimada A, Kimura J, Takeda T (1993) Beta/A4 protein like immunoreactive granular structures in the brain of senescence-accelerated mouse. Am J Pathol 142, 1887-1897.

[191] Akiyama H, Kameyama M, Akiguchi I, Sugiyama H, Kawamata T, Fukuyama H, Kimura H, Matsushita M, Takeda T (1986) Periodic acid-Schiff (PAS)-positive, granular structures increase in the brain of senescence accelerated mouse (SAM). Acta Neuropathol 72, 124-129.

[192] Manich G, del Valle J, Cabezón I, Camins A, Pallàs M, Pelegrí C, Vilaplana J (2014) Presence of a neo-epitope and absence of amyloid beta and tau protein in degenerative hippocampal granules of aged mice. Age (Dordr) 36, 151165.

[193] Jack CR Jr, Knopman DS, Jagust WJ, Shaw LM, Aisen PS, Weiner MW, Petersen RC, Trojanowski JQ (2010) Hypothetical model of dynamic biomarkers of the Alzheimer's pathological cascade. Lancet Neurol 9, 119-128.

[194] Canudas AM, Gutierrez-Cuesta J, Rodríguez MI, AcuñaCastroviejo D, Sureda FX, Camins A, Pallàs M (2005) Hyperphosphorylation of microtubule-associated protein tau in senescence-accelerated mouse (SAM). Mech Ageing Dev 126, 1300-1304.

[195] Álvarez-García O, Vega-Naredo I, Sierra V, Caballero B, Tomás-Zapico C, Camins A, García JJ, Pallàs M, CotoMontes A (2006) Elevated oxidative stress in the brain of senescence-accelerated mice at 5 months of age. Biogerontology 7, 43-52.

[196] Orejana L, Barros-Miñones L, Jordán J, Puerta E, Aguirre N. (2012) Sildenafil ameliorates cognitive deficits and tau pathology in a senescence-accelerated mouse model. $\mathrm{Neu}$ robiol Aging 33, 625.e11-20. 
[197] Farr SA, Sandoval KE, Niehoff ML, Witt KA, Kumar VB, Morley JE (2016) Peripheral administration of GSK-3 $\beta$ antisense oligonucleotide improves learning and memory in SAMP8 and Tg2576 mouse models of Alzheimer's disease. J Alzheimers Dis 54, 1339-1348.

[198] Harman D (2002) Alzheimer's disease: Role of aging in pathogenesis. Ann N Y Acad Sci 959, 384-395.

[199] Sato E, Kurokawa T, Oda N, Ishibashi S (1996) Early appearance of abnormality of microperoxisomal enzymes in the cerebral cortex of senescence-accelerated mouse. Mech Ageing Dev 92, 175-184.

[200] Yasui F, Ishibashi M, Matsugo S, Kojo S, Oomura Y, Sasaki K (2003) Brain lípid hydroperoxide level increases in senescence-accelerated mice at an early age. Neurosci Lett 350, 66-68.

[201] Fujibayashi Y, Yamamoto S, Waki A, Konishi J, Yonekura $Y$ (1998) Increased mitochondrial DNA deletion in the brain of SAMP8, a mouse model for spontaneous oxidative stress brain. Neurosci Lett 254, 109-112.

[202] Sureda FX, Gutierrez-Custa J, Romeu M, Mulero M, Canudas AM, Camins A, Mallol J, Pallàs M (2006) Changes in oxidative stress parameters and neurodegeneration markers in the brain of the senescence-accelerated mice SAMP-8. Exp Gerontol 41, 360-367.

[203] Okatani Y, Wakatsuki A, Reiter RJ, Miyahara Y (2002) Melatonin reduces oxidative damage of neural lípids and proteins in senescence-accelerated mouse. Neurobiol Aging 23, 639-644.

[204] Butterfield DA, Howard BJ, Yatin S, Allen KL, Carney JM (1997) Free radical oxidation of brain proteins in accelerated senescence and its modulation by N-tertbutyl-alpha-phenylnitrone. Proc Natl Acad Sci U S A 94, 674-678.

[205] Caballero B, Vega-Naredo I, Sierra V, DeGonzaloCalvo D, Medrano-Campillo P, Guerrero JM, Tolivia D, Rodríguez-Colunga MJ, Coto-Montes A (2009) Autophagy upregulation and los of NF-KappaB in oxidative stress-related immunodeficient SAMP8 mice. Mech Ageing Dev 130, 722-730.

[206] Ginés C, Cuesta S, Kireev R, García C, Rancan L, Paredes SD, Vara E, Tresguerres JA (2017) Protective effect of resveratrol against inflammation, oxidative stress and apoptosis in pancreas of aged SAMP8 mice. Exp Gerontol 90, 61-70.

[207] Nishikawa T, Takahashi JA, Fujibayashi Y, Fujisawa H, Zhu B, Nishimura Y, Ohnishi K, Higuchi K, Hashimoto N, Hosokawa M (1998) An early stage mechanism of the age-associated mitochondrial dysfunction in the brain of SAMP8 mice; an age-associated neurodegeneration animal model. Neurosci Lett 254, 69-72.

[208] García-Matas S, Gutierrez-Cuesta J, Coto-Montes A, Rubio-Acero R, Díez-Vives C, Camins A, Pallàs M, Sanfeliu C, Cristòfol R (2008) Dysfunction of astrocytes in senescence-accelerated mice SAMP8 reduces their neuroprotective capacity. Aging Cell 7, 630-640.

[209] García-Matas S, Paul RK, Molina-Martínez P, Palacios H, Gutierrez VM, Corpas R, Pallàs M, Cristòfol R, de Cabo $\mathrm{R}$, Sanfeliu C (2015) In vitro caloric restriction induces protective genes and functional rejuvenation in senescent SAMP8 astrocytes. Aging Cell 14, 334-344.

[210] Cristòfol R, Porquet D, Corpas R, Coto-Montes A, Serret J, Camins A, Pallàs M, Sanfeliu C (2012) Neurons from senescence-accelerated SAMP8 mice are protected against frailty by the sirtuin 1 promoting agents melatonin and resveratrol. J Pineal Res 52, 271-281.
[211] Nakahara H, Kanno T, Inai Y, Utsumi K, Hiramatsu M, Mori A, Packer L (1998) Mitochondrial dysfunction in the senescence accelerated mouse (SAM). Free Radic Biol Med 24, 85-92.

[212] Okatani Y, Wakatsuki A, Reiter RJ, Miyahara Y (2002) Hepatic mitochondrial dysfunction in senescenceaccelerated mice: Correction by long-term, orally administered physiological levels of melatonin. J Pineal Res 33, 127-133.

[213] Rodríguez MI, Escames G, López LC, López A, García JA, Ortiz F, Sánchez V, Romeu M, Acuña-Castroviejo D (2008) Improved mitochondrial function and increased life span after chronic melatonin treatment in senescent prone mica. Exp Gerontol 43, 749-756.

[214] Castellani RJ, Lee HG, Siedlak SL, Nunomura A, Hayashi T, Nakamura M, Zhu X, Perry G, Smith MA (2009) Reexamining Alzheimer's disease: Evidence for a protective role for amyloid-beta protein precursor and amyloid-beta. J Alzheimers Dis 18, 447-452.

[215] Morley JE, Farr SA, Banks WA, Johnson SN, Yamada KA, $\mathrm{Xu}$ L (2010) A physiological role for amyloid-beta protein: Enhancement of learning and memory. J Alzheimers Dis 19, 441-449.

[216] Morley JE, Armbrecht HJ, Farr SA, Kumar VB (2012) The senescence mouse (SAMP8) as a model for oxidative stress and Alzheimer's disease. Biochim Biophys Acta 1822, 650-656.

[217] Butterfield DA, Swomley AM, Sultana R (2013) Amyloid (-peptide (1-42)-induced oxidative stress in Alzheimer disease: Importance in disease pathogenesis and progression. Antioxid Redox Signal 19, 823-835.

[218] García-Matas S, de Vera N, Aznar AO, Marimon JM, Adell A, Planas AM, Cristòfol R, Sanfeliu C (2010) In vitro and in vivo activation of astrocytes by amyloid-beta is potentiated by pro-oxidant agents. J Alzheimers Dis $\mathbf{2 0}$, 229-245.

[219] García-Mesa Y, Colie S, Corpas R, Cristòfol R, Comellas F, Nebreda AR, Giménez-Llort L, Sanfeliu C (2016) Oxidative Stress is a central target for physical exercise neuroprotection against pathological brain aging. J Gerontol A Biol Sci Med Sci 71, 40-49.

[220] Singh AK, Bissoyi A, Kashyap MP, Patra PK, Rizvi SI (2017) Autophagy activation alleviates amyloid-betainduced oxidative stress, apoptosis and neurotoxicity in human neuroblastoma SH-SY5Y cells. Neurotox Res 32, 351-361.

[221] França MB, Lima KC, Eleutherio EC (2017) Oxidative stress and amyloid toxicity: Insights from yeast. $J$ Cell Biochem 118, 1442-1452.

[222] Poon HF, Joshi G, Sultana R, Farr SA, Banks WA, Morley JE, Calabrese V, Butterfield DA (2004) Antisense directed at the Abeta region of APP decreases brain oxidative markers in aged senescence accelerated mice. Brain Res 1018, 86-96.

[223] Tönnies E, Trushina E (2017) Oxidative stress, synaptic dysfunction and Alzheimer's disease. J Alzheimers Dis 57, 1105-1121.

[224] Persson T, Popescu BO, Cedazo-Minguez A (2014) Oxidative stress in Alzheimer's disease: Why did antioxidant therapy fail? Oxid Med Cell Longev 2014, 427318.

[225] Bagyinszky E, Giau VV, Shim K, Suk K, An SSA, Kim S (2017) Role of inflammatory molècules in the Alzheimer's disease progression and diagnosis. J Neurol Sci 376, 242254. 
[226] Bolós M, Perea JR, Avila J (2017) Alzheimer's disease as an inflammatory disease. Biomol Concepts 8, 37-43.

[227] Alvarez-López MJ, Molina-Martínez P, Castro-Freire M, Cosín-Tomás M, Cristòfol R, Párrizas M, Escorihuela RM, Pallàs M, Sanfeliu C, Kaliman P (2014) Rcor2 underexpression in senescent mice: A target for inflammaging? J Neuroinflammation 11, 126.

[228] Cuesta S, Kireev R, Forman K, García C, Escames G, Ariznavarreta C, Vara E, Tresguerres JA (2010) Melatonin improves inflammation processes in liver of senescenceaccelerated prone male mice (SAMP8). Exp Gerontol 45, 950-956.

[229] Tha KK, Okuma Y, Miyazaki H, Murayama T, Uehara T, Hatakeyama R, Hayashi Y, Nomura Y (2000) Changes in expressions of proinflammatory cytokines IL-1beta, TNFalpha and IL- 6 in the brain of senescence accelerated mouse (SAM) P8. Brain Res 885, 25-31.

[230] Wang HM, Wang LW, Liu XM, Li CL, Xu SP, Farooq AD (2013) Neuroprotective effects of forsythiaside on learning and memory deficits in senescence-accelerated mouse prone (SAMP8) mice. Pharmacol Biochem Behav 105, 134-141.

[231] Wang X, Puerta E, Cedazo-Minguez A, Hjorth E, Schultzberg M (2015) Insufficient resolution response in the hippocampus of a senescence-accelerated mouse model SAMP8. J Mol Neurosci 55, 396-405.

[232] Gutierrez-Cuesta J, Sureda FX, Romeu M, Canudas AM, Caballero B, Coto-Montes A, Camins A, Pallàs M (2007) Chronic administration of melatonin reduces cerebral injury biomarkers in SAMP8. J Pineal Res 42, 394-402.

[233] Griñan-Ferré C, Puigoriol-Illamola D, Palomera-Ávalos V, Pérez-Cáceres D, Companys-Alemany J, Camins A, Ortuño-Sahagún D, Rodrigo MT, Pallàs M (2016) Environmental enrichment modified epigenetic mechanisms in SAMP8 mouse hippocampus by reducing oxidative stress and inflammaging and achieving neuroprotection. Front Aging Neurosci 8, 241.e.

[234] Li G, Cheng H, Zhang X, Shang X, Xie H, Zhang X, Yu J, Han J (2013) Hippocampal neuron loss is correlated with cognitive deficits in SAMP8 mice. Neurol Sci 34, 963-969.

[235] Sanabria-Castro A, Alvarado-Echevarría I, MongeBonilla C (2017) Molecular pathogenesis of Alzheimer's disease: An update. Ann Neurosci 24, 46-54.

[236] Butterfield DA, Poon HF (2005) The senescenceaccelerated prone mouse (SAMP8): A model of age-related cognitive decline with relevance to alterations of the gene expression and protein abnormalities in Alzheimer's disease. Exp Gerontol 40, 774-783.

[237] Díez-Vives C, Gay M, García-Matas S, Comellas F, Carrascal M, Abian J, Ortega-Aznar A, Cristòfol R, Sanfeliu C (2009) Proteomic study of neuron and astrocyte cultures from senescence-accelerated mouse SAMP8 reveals degenerative changes. J Neurochem 111, 945-955.

[238] Ortuño-Sahagún D, Pallàs M, Rojas-Mayorquín AE (2014) Oxidative stress in anging: Advances in proteomic approaches. Oxid Med Cell Long 2014, 573208.
[239] Wang J, Liu Y, Cheng X, Zhang X, Liu F, Liu G, Qiao S, Ni M, Zhou W, Zhang Y, Li F (2017) The effects of LW-AFC on the hippocampal transcriptome in senescence-accelerated mouse prone 8 strain, a mouse model of Alzheimer's disease. J Alzheimers Dis 57, 227240.

[240] Currais A, Goldberg J, Farrokhi C, Chang M, Prior M, Dargusch R, Daugherty D, Armando A, Quehenberger O, Maher P, Schubert D (2015) A comprehensive multiomics approach toward understanding the relationship between aging and dementia. Aging 7, 937-955.

[241] Palomera-Avalos V, Griñán-Ferré C, Puigoriol-Illamola D, Camins A, Sanfeliu C, Canudas AM, Pallàs M (2017) Resveratrol protects SAMP8 brain under metabolic stress: Focus on mitochondrial function and Wnt pathway. Mol Neurobiol 54, 1661-1676.

[242] Wang CM, Tsai SN, Yew TW, Kwan YW, Ngai SM (2010) Identification of histone methylation multiplicities patterns in the brain of senescence-accelerated prone mouse 8. Biogerontology 11, 87-102.

[243] Yu N, Liu J, Yi G, Ye F, Xiao J, Guo F (2015) DNA methylation is necessary for erythropoietin to improve spatial learning and memory in SAMP8 mice. Exp Gerontol 69, 111-115.

[244] Griñán-Ferré C, Sarroca S, Ivanova A, Puigoriol-Illamola D, Aguado F, Camins A, Sanfeliu C, Pallàs M (2016) Epigenetic mechanisms underlying cognitive impairment and Alzheimer disease hallmarks in 5XFAD. Aging 8, 664684.

[245] Niwa R, Zhou F, Li C, Slack FJ (2008) The expression of the Alzheimer's amyloid precursor protein-like gene is regulated by developmental timing microRNAs and their targets in Caenorhabditis elegans. Dev Biol 315, 418-425.

[246] Liu W, Liu C, Zhu J, Shu P, Yin B, Gong Y, Qiang B, Yuan J, Peng X (2012) MicroRNA-16 targets amyloid precursor protein to potentially modulate Alzheimer's-associated pathogenesis in SAMP8 mice. Neurobiol Aging 33, 522534.

[247] Tang Y, Bao JS, Su JH, Huang W (2017) MicroRNA139 modulates Alzheimer's-associated pathogenesis in SAMP8 mice by targeting cannabinoid receptor type 2 . Genet Mol Res 16. doi: 10.4238/gmr16019166

[248] Cheng X, Cui X, Zheng Y, Zhang GR, Li P, Huang H, Zhao YY, Bo XC, Wang SQ, Zhou WX, Zhang YX (2013) Nodes and biological processes identified on the basis of network analysis in the brain of the senescence accelerated mice as an Alzheimer's disease animal model. Front Aging Neurosci 5, 65.

[249] Liu W, Liu C, Yin B, Peng XZ (2015) Functions of miR-9 and miR-9* during aging in SAMP8 mice and their possible mechanisms. Zhongguo Yi Хие Ке Хие Yuan Xие Bao 37, 253-258. 